\title{
Abnormal inventory and performance in manufacturing companies: evidence from the trade credit channel
}

\section{Godfred Adjapong Afrifa ${ }^{1} \cdot$ Ahmad Alshehabi $^{2} \cdot$ Ishmael Tingbani $^{3} \cdot$ Hussein Halabi $^{4}$}

Published online: 30 June 2020

(c) The Author(s) 2020

\begin{abstract}
This paper examines the value of abnormal inventory and the channels through which firms decrease abnormally high inventory or increase abnormally low inventory for a sample of 976 United Kingdom manufacturing firms over the period from 2006 to 2015 . Using GMM regressions, the results show that (i) an optimal inventory policy exists; and (ii) firms that are able to converge at this optimal inventory level by either decreasing abnormally high inventory or increasing abnormally low inventory to improve operational and stock performance. Importantly, the results show that trade receivables and trade payables are the channels through which firms achieve efficient inventory management.
\end{abstract}

Keywords Abnormal inventory $\cdot$ Firm performance $\cdot$ Trade receivables $\cdot$ Trade payables · Firm risk

JEL Classification D22 · G31 · G32

\section{Introduction}

Inventory management is fundamental to firms' performance because it represents a huge investment in working capital (Blinder and Maccini 1991; Valderrama 2003), especially for manufacturing firms. However, the optimal control of inventory remains a key challenge to

Godfred Adjapong Afrifa

G.A.Afrifa@kent.ac.uk

Ahmad Alshehabi

ahmad.alshehabi@canterbury.ac.uk

Ishmael Tingbani

itingbani@bournemouth.ac.uk

Hussein Halabi

hussein.halabi@swansea.ac.uk

1 Kent Business School, University of Kent, Canterbury CT2 7PE, UK

2 Christ Church Business School, Canterbury Christ Church University, Canterbury CT1 1QU, UK

3 Bournemouth University, 89 Holdenhurst Road, Bournemouth BH8 8EB, UK

4 School of Management, Swansea University, Swansea SA1 8EN, UK 
firms (Van Horenbeek et al. 2013). For example, during 2015, the leading 2000 companies in the United States of America (USA) and Europe had approximately $\$ 187.5$ billion and $\$ 820$ billion unnecessarily invested in inventory, respectively, ${ }^{1}$ which shows evidence of inefficiencies in inventory management. In recent times, however, many firms (see, e.g., Burberry Group Plc) have focused on inventory management as a potential avenue for cost savings because of its informativeness to firm value (Bao and Bao 2004). For example, several firms have been using advanced computer technology for inventory control (Madhou et al. 2015). However, prior studies have circumvented examining the value effect of abnormal inventory and avenues through which firms translate abnormal inventory into superior performance.

Against this backdrop, this paper examines the relationship between abnormal inventory and performance of United Kingdom (UK) manufacturing firms. A research on inventory management is highly salient and timely, especially for British manufacturing industries that are heavily integrated into European supply chains, and will therefore be heavily affected by Brexit. This break in the relationship between the UK and EU necessitates the need for UK manufacturing firms to revise their procurement policy and diversify their supplier base by the inclusion of non-EU suppliers. Therefore, UK manufacturing firms must optimally determine the level of inventory holdings that maximises performance.

A firm may have an abnormally high inventory (i.e. a higher actual than predicted inventory) or an abnormally low inventory (i.e. a lower actual than predicted inventory). There are several theoretical arguments proposed in the literature to explain the relationship between abnormal inventory and firm performance. Abnormally high inventory may have adverse effects leading to value destruction for shareholders (Hendricks and Singhal 2005). Abnormally high inventory could indicate that a firm is struggling to generate sales (Lev and Thiagarajan 1993). Additionally, like all investments, inventory requires additional financing, which will increase the interest expenses of the firm (Aktas et al. 2015). The magnitude of capital locked up in inventory presents an opportunity cost to firms (Kieschnick et al. 2013), which may reduce performance. Abnormally high inventory may also increase the risk of bankruptcy of a firm and threaten its survival (Shin and Soenen 1998) because of the strain on cash flow. Abnormally high inventory may stifle cash flow and inhibit a firm from investing in profitable projects (Baños-Caballero et al. 2014). Indirectly, abnormally high inventory may impede a firm's bargaining power because of the urgent need to sell, giving customers the upper hand (Singhal 2005). Abnormally high inventory also has the potential to restrict a firm's capacity to launch new products into the market due to the need to clear the distribution channel of existing inventory (Singhal 2005).

Owing to the discussion that abnormally high inventory is value decreasing, the natural question will be, why do firms not continually reduce their inventory levels? It must, however, be noted that inventory holding also has some benefits. That is, firms with abnormally low inventory can increase performance by increasing investment in inventory. According to the precautionary motive of inventory management, firms maintain inventory to avoid the prospect of a stock-out situation (Wen 2005; Afrifa 2016). The speculative motive of inventory management also suggests that firms hold inventory in order to increase profitability in the future (Hill and Sartoris 1992; Morgan 1991) through expected increase in future prices. Inventory can provide a hedge against input price fluctuation (Blinder and Maccini 1991) and prevent loss of client business (Wang

\footnotetext{
1 Source: Ernst and Young working capital report entitled "All tied up". This report is the seventh annual publication reviewing the working capital performance of the world's largest companies. The survey focuses on the top 2000 companies in the US and Europe.
} 
2002). Inventory may also prevent a firm from emergency buying (Afrifa and Gyapong 2017). The existence of potential costs and benefits of holding inventory implies a nonlinear relation between abnormal inventory and firm performance. We therefore expect the relationship to be negative for firms with abnormally high inventory and firms with abnormally low inventory, i.e. only the decrease (or increase) of abnormally high (abnormally low) inventory should lead to superior firm performance.

It is worth mentioning here that managers may use inventory management, by manipulating inventory account (accrual manipulation) or by engaging in overproduction (real activity manipulation), to report higher earnings (Gu et al. 2005; Kothari et al. 2005; Cohen and Zarowin 2010; Li 2014; Halabi et al. 2019; Xu et al. 2019). This is different from the 'efficient' management of inventory, which requires firms to reduce their deviations from the 'optimal' level of inventory in order to maximise their financial/ stock performance. This can be done by two ways: either by decreasing abnormally high inventory or increasing abnormally low inventory, i.e. not a mere increase in inventory, which is the case of earnings management through inventory.

We begin our empirical analysis by exploring how abnormally high and low inventory levels affect firm performance using both linear and asymmetric models. The results, using GMM regressions on a sample of 976 manufacturing firms in the UK over the period 2006-2015, show an optimal inventory holding that improves firm performance and that firms which decrease (increase) their abnormally high (low) inventory enjoy higher performance.

After determining the effects of abnormally high and low inventory on firms' performance, we then analyse the channels through which firms are able to reduce (increase) their abnormally high (low) inventory. The results show that firms decrease (increase) their abnormally high (low) inventory via trade receivables and trade payables respectively.

We then examine whether the decrease (increase) in abnormally high (low) inventory via the trade receivables (trade payables) channel is one which leads to higher firm performance. The use of interaction variables confirms our expectations that the decrease of abnormally high inventory via trade receivables and the increase of abnormally low inventory via trade payables maximise firm performance.

Finally, we examine whether firm risk drives the performance effect of abnormally high and low inventory. The results show that whereas abnormally high inventory has a positive relationship with firm risk, abnormally low inventory negatively affects firm risk. These results strengthen the arguments of our main regression results by suggesting that decreases (increases) in abnormally high (low) inventory do not increase firm risk. It therefore rules out the proposition that firm risk is an alternative explanation for the positive association between decrease (increase) in abnormally high (low) inventory and firm performance.

Our study makes several important contributions to the existing literature. First, our study is the first to examine the impact of both abnormally high and low inventory amounts on the firm's performance, employing an advanced and robust method to calculate the firms' abnormal inventory amounts. Previous studies have mainly examined the effect of firms' normal inventory amount on performance (Capkun et al. 2009). However, this paper extends prior literature by examining the impact of abnormal inventory on firm performance. To the best of our knowledge, this method has never been applied in the inventory management literature, despite being widely used in other research areas such as working capital management (Aktas et al. 2015) and corporate governance (Enos and Gyapong 2017).

The study by Chen et al. (2005) is the only one to examine the association between firms' abnormal inventory and stock market performance. They used the normalised 
deviations of each firm's inventory holding to their industry peers, which may not be sufficiently sensitive to detect the impact of firm-specific characteristics on abnormal inventory.

Second, our study explores the impact of firms' abnormal inventory on total risk and provides new empirical evidence that the successful optimisation of inventory aids firms in reducing their total stock return volatility. Thus, the optimisation of inventory improves not only firm performance but also their survival.

Third, and most importantly, we also contribute to the inventory management literature by examining the channels (i.e. trade payables and trade receivables) through which firms can translate their abnormal inventory into higher performance, an area of research where there is a lack of empirical evidence. Prior studies, however, have mainly focused their investigation on the association of trade credit with either firm performance (Hill et al. 2012; Martínez-Sola et al. 2014) or normal inventory amounts (Guariglia and Mateut 2016). A more recent paper by $\mathrm{Xu}$ et al. (2020) shows how corporate social responsibility positively influences firms' access to trade credit. Our study extends their work by examining how firms, in their attempt to improve their performance, can optimise their level of inventory via trade credit channels.

The rest of the paper is structured as follows: Sect. 2 discusses the theoretical and empirical literature on inventory and firm performance and develops hypotheses, followed in Sect. 3 by the study data and research methodology. Section 4 discusses the empirical results, followed by further analysis in Sect. 4.2. The penultimate section provides the robustness tests, and the final section concludes the paper.

\section{Theory, literature review, and hypotheses}

\subsection{Inventory and firm performance - theoretical framework}

Theories provide several arguments about the relationship between inventory and firm performance. First, the precautionary motive theory suggests a positive association between inventory and firm performance. This theory argues for the need to hold more inventory in order to avoid the prospect of stock-out situations (Wen 2005). A stock-out situation may cause a firm to lose both current and prospective customers. Therefore, the prevention of a stock-out situation may help avoid the loss of sales. Further, this theory suggests a higher level of inventory because of uncertainty in the lead time of delivery. Generally, firms may need extra inventory in between the time they place the order until deliveries are received. There are also unavoidable delays in delivery in addition to the normal lead time, which may, therefore, warrant the holding of higher inventory. The precautionary motive theory advocates for firms to be more precautious by being more conservative in their inventory policy. Although this theory makes business sense, it can only become value enhancing if the benefits of holding the extra inventory will outweigh the costs. There are several costs associated with the holding of inventory including warehousing cost, heating, lighting, etc.

The second theory is the speculative motive theory, which also proposes a positive association between higher inventory and firm performance. This theory argues that firms can enhance performance by realising abnormal profits as a result of holding higher inventory. The abnormal profits are realised because prices are expected to ordinarily rise in the future, and therefore buying inventory now and selling it later should result in higher profitability. Hill and Sartoris (1992) argue that the speculative motive theory of inventory only works best in inflationary periods. For example, Morgan (1991) suggests that the 
rapid inflation in the late 1970s and early 1980s motivated companies to increase inventory before prices rose. For this theory to work best, the future expected price increases should be high enough to cover the cost of holding the inventory. However, given the low inflation rates in recent years, especially in the Western world, this motive of holding inventory may not be value enhancing.

The third theory is the transaction cost theory (Ferris 1981), which predicts a negative association between inventory and firm performance. This theory suggests two factors that influence the effect of inventory reduction on firm performance. First, the theory proposes that firms can improve performance by keeping only the minimum level of inventory necessary to meet expected demand and production (Bhattacharya 2008). The keeping of minimum required inventory should improve firm performance by reducing the costs associated with the holding of extra inventory. Second, the theory proposes the shifting of inventory from the supplier to the customer through trade credit, which reduces the costs of holding inventory (Ferris 1981; Petersen and Rajan 1997; Bougheas et al. 2009). The downside to this theory is that keeping the minimum required inventory could increase the risk to a firm in the event of unexpected delivery delays and inventory shortages. Also, although the shifting of inventory to customers through trade credit may improve inventory turnover and profitability, it could also result in bad debts and late payments. These have the potential of harming the cash flow and performance of the firm (Fullerton et al. 2003).

The final theory to discuss in this paper is the Just-In-Time (JIT), which was developed by Taiichi Ohno for Toyota in the 1950s and 1960s (Monden 1983). This theory of inventory management views the keeping of inventory as the root of all evil (Hsieh and Kleiner 1992), and therefore advocates for a zero level of inventory (Harrison 1992). It recognises the various costs of holding inventory and argues that inventory does not add value to the product (Morgan 1991). This theory therefore proposes a negative relationship between inventory holding and firm performance. Several prior studies (Huson and Nanda 1995; Fullerton et al. 2003) have examined the relationship between JIT implementation of inventory management and firm performance. These studies all postulate a positive association between JIT implementation and firm performance. Although the implementation of JIT requires significant organisational change and effort (Pong and Mitchell 2012), such as forging a closer relationship with more dependable suppliers (Younies et al. 2007), most firms that successfully implement it report substantial cost savings. For example, Johnson (1986) found that General Motors made cost savings of about \$6 billion after implementing the JIT technique to its inventory management. However, this technique of inventory management has been widely criticised by academic researchers and financial commentators as a ploy by larger firms to push inventory to their smaller suppliers (Morgan 1991).

\subsection{Inventory and firm performance-empirical literature}

The empirical work of Aktas et al. (2015) found that among the three components of net working capital, ${ }^{2}$ inventory offers the most pronounced effect on firm performance. That is, changes in inventory are more sensitive to firm performance than both trade receivables and payables. Singhal (2005) studied the effect of abnormal inventory announcement on firm performance and found a significant association. He, therefore, argues that inventory contains incremental information useful to predict both demand and expenses. Chen et al.

${ }^{2}$ Working capital is calculated as inventories plus trade receivables minus trade payables. 
(2005) examined the association between inventory and firm performance, and found that firms with abnormally high inventory levels relative to industry peers experienced poor stock performance. Cachon and Fisher (1997) suggest that poor operational performance on the supply-demand mismatches is mainly attributable to abnormal inventories.

In support of a negative association between inventory and firm performance, Huson and Nanda (1995) found that firms which adopt JIT have higher earnings per share than those not using JIT. Similarly, Kinney and Wempe (2002) found that firms that use JIT improved their profit margin performance relative to non-users. Fullerton et al. (2003) found in their study that reductions in inventory have a strong association with improved returns on assets, returns on sales, and cash-flow margin. Chen et al. (2007) found correlation between inventory changes and abnormal stock market returns. Demeter (2003) also examined the association between inventory and firm performance and suggests that decreases in inventory lead to higher returns on sales. Using a sample of retail firms, Bernard and Noel (1991) report that inventory predicts earnings in the retail industry. In a Belgium context, Deloof (2003) found that decreases in inventory enhance Belgium firms' performance.

Contrary to the negative association between inventory and firm performance, other studies also report a positive relationship. Using a sample of 3057 firms during the 1989-2004 period, Obermaier and Donhauser (2012) found a positive association between inventory-to-sales ratio and firm performance. They therefore concluded that firms with the lowest (highest) inventory level also have the worst (better) performance level. They further discuss that too low level of inventory makes it difficult for firms to run more costefficiently. Chen et al. (2005) postulate in their study of publicly traded American manufacturing firms between 1981 and 2000 that firms with inventory level slightly more negative than the average perform better than firms with extremely low inventory level.

\subsection{Hypothesis development}

\subsubsection{Abnormal inventory and firm performance}

A decrease in inventory, especially for firms with abnormally high inventory, is expected to be value increasing. This is because decreases in abnormally high inventory free up cash, which may help to avoid the prospect of a firm seeking short-term funds to finance profitable ventures (Fullerton et al. 2003). Inventory, like all other investments, requires financing (Kieschnick et al. 2013), and therefore firms with abnormally high inventory face higher interest charges and bankruptcy risk (Aktas et al. 2015). A decrease in abnormally high inventory minimises the various costs associated with holding inventory (e.g. warehouse cost, spoilage, obsolescence) (Afrifa and Gyapong 2017). It is suggested that the cost of carrying inventory ranges from 20 to $40 \%$ of inventory value (Ballou 2000). As a result, Drury (2013) proposes that the opportunity to reduce overheads and capital employed is better achieved through inventory reduction. Abnormally high inventory reduces performance because it leads to instances of price concessions and inventory write-offs (Hendricks and Singhal 2014). Abnormally high inventory also creates the situation of demand-supply mismatch, which is expected to have a negative effect on firm performance (Raman 1997).

On the other hand, an increase of abnormally low inventory is expected to improve firm performance (Chen et al. 2005). This is because inventory averts production and trading interruptions (García-Teruel and Martinez-Solano 2007). Increasing abnormally 
low inventory may improve firm performance by reducing the risk of a stock-out situation (Deloof 2003), liberating a firm from price fluctuations (Blinder and Maccini 1991), and stimulating sales (Deloof 2003), thus preventing loss of client business (Wang 2002). Increasing abnormally low inventory may also increase performance by preventing a firm from emergency buying. Therefore, ceteris paribus, the existence of these potential costs and benefits associated with both abnormally high and abnormally low inventory implies an optimal inventory level at which firm performance is enhanced. In fact, Chowdhury and Amin (2007) argue that both excessive and inadequate inventory is harmful to a firm. Moreover, Obermaier and Donhauser (2012) argue that inventory is not always a drawback because although its holdings cost money, inventory does have some benefits as well. The preceding discussions lead to the following hypothesis:

H1 There is a non-linear (concave) relationship between abnormal inventory and firm performance: a positive relation at abnormally low inventory and a negative relation at abnormally high inventory.

\subsubsection{Abnormal inventory and trade receivables}

According to Caglayan et al. (2012), firms reduce inventory by selling to customers on credit. We propose in this paper that the value enhancing of a decrease in abnormally high inventory is achieved through trade receivables. Given the various costs associated with the holding of inventory (Obermaier and Donhauser 2012), the firm with abnormally high inventory will have an urgent need to reduce inventory (Banker et al. 2019), which can be achieved by selling to customers on credit (Caglayan et al. 2012). The literature argues that the best way that firms can reduce inventory is through trade receivables (Mateut et al. 2015). Ferris (1981) suggests that firms can use trade receivables to optimise inventory levels. Choi and Kim (2005) argue that firms increase the portion of sales on credit when inventory accumulates.

Selling on credit essentially transfers the costs of holding inventory to the customer, and by so doing firms may be able to increase their sales growth (Guariglia and Mateut 2016) and establish a long-term relationship with customers (Long et al. 1993). Credit to customers, on the other hand serves as a source of finance for customers (García-Teruel and Martínez-Solano 2010). Therefore, using trade receivables as the channel through which to reduce abnormally high inventory may improve performance (Ek and Guerin 2011). This may allow the firm to embark on value-enhancing investment projects (Aktas et al. 2015). Bougheas et al. (2009) argue that the use of trade receivables leads to a better inventory management. Ferrando and Mulier (2013) postulate that the minimisation of inventory costs implies an increase in trade receivables. Guariglia and Mateut (2016) found that firms sell on credit in an attempt to reduce the costly stocks of inventory. This leads to the following hypothesis:

H2 There is a positive relationship between the decrease of abnormally high inventory and trade receivables.

\subsubsection{Abnormal inventory and trade payables}

Firms with abnormally low inventory can avoid out-of-stock costs by increasing inventory levels. Because of the costs associated with running out of stock (Afrifa 2016), firms with 
abnormally low inventory will have an urgent need to replenish it, which can be achieved by buying on credit and paying later (Goto et al. 2015). Also, a firm with abnormally low inventory will have to purchase more than normal; therefore there is the need to request credit from suppliers. Caglayan et al. (2012) state that firms increase their inventory when they buy from suppliers on credit.

We propose in this paper that the value enhancing of an increase of abnormally low inventory is achieved through trade payables. Suppliers' credit provides a flexible avenue for firms to acquire the necessary inputs without having to make immediate payment (Ferrando and Mulier 2013), helping firms to overcome the inefficiencies in the financial market (Petersen and Rajan 1997). Since credit is arranged directly with the supplier, firms can increase inventory spontaneously to meet any shortfall. Thus, firms can use trade payables to optimise inventory levels. Suppliers' credit is the main source of inventory financing (Demirgüç-Kunt and Maksimovic 1999) because it is easier to arrange than a bank loan (Abdulla et al. 2017). In fact, over $80 \%$ of merchandise in the UK is financed by suppliers' credit (Peel et al. 2000). The use of trade payables to increase abnormally low inventory is expected to improve firm performance because they improve operating efficiency through the separation of payment from delivery (Ferris 1981; Nilsen 2002) and smooth production cycles (Petersen and Rajan 1997). Relying on suppliers' credit through trade payables also improves performance by allowing firms to channel funds to more productive use (Goto et al. 2015). Following the above arguments, it is hypothesised that:

H3 There is a positive relationship between the increase of abnormally low inventory and trade payables.

\section{Research design}

\subsection{Sample and data}

Following previous researchers (e.g. Capkun et al. 2009), and in order to reduce the heterogeneity across the sample firms because "different industries have different inventory needs" (Chen et al. 2005), we restricted our sample to manufacturing firms. Unlike other industries, manufacturing firms tend to keep all three forms of inventory (raw materials, work-in-process, and finished goods), and as a result of that they tend to have higher amounts of inventories as a percentage of their total assets (Guariglia 1999; Capkun et al. 2009).

We obtained financial data from Datastream over the 2006-2015 period. The sample represents all UK manufacturing firms whose shares are publicly traded on the London Stock Exchange (LSE). The final sample consists of unbalanced panels of 8431 annual observations from 2006 to 2015 for 976 UK manufacturing firms entering and exiting the dataset.

\subsection{Variables definitions}

\subsubsection{Abnormal inventory}

The main variable of interest is the abnormal inventory-to-sales ratio, denoted abnormal inventory throughout this paper. Following prior studies (Hill et al. 2010; Aktas et al. 
2015), we initially predicted the optimal inventory-to-sales ratio using the following variables: financial distress, sales growth, firm size, sales volatility, capital expenditure, firm age, and operating cash flow. The inventory-to-sales ratio is regressed for each year and sub-industry using the UK SIC 2007 industry classification (see "Appendix 1"). In total, there are 14 manufacturing sub-industries over a 10 -year period, leading to 140 industry/ year regressions, by construction. ${ }^{3}$

The fit of the first-stage model including the Fisher-statistic, adjusted R-square, and number of observations used in the regressions are presented in "Appendix 2". The mean Fisher-statistic is 3.40, which shows that the first-stage regressions fit sufficiently well with the data. On average, the adjusted R-square is $29.07 \%$, higher than that reported by Aktas et al. (2015). The number of observations per each first stage regression is 65 , on average.

The predicted values from the first-stage regression represent the optimal inventory for each firm/year. Therefore, abnormal inventory for each firm/year is the difference between the actual inventory-to-sales ratio minus its predicted value from the first-stage regression. According to this computation, abnormal inventory can be high or low. Abnormally high inventory suggests that the firm is over-investing in inventory because the predicted inventory-to-sales ratio is lower than the actual inventory-to-sales ratio. This indicates that there is avenue for the firm to efficiently manage its inventory across time by embracing a comparatively more aggressive policy through inventory reduction. Abnormally low inventory means the firm is under-investing in inventory because the predicted inventory ratio is higher than the actual inventory ratio. This means that the firm should be embracing a more conservative policy through inventory increase, to avoid the risk of production interruptions and sales losses (Blinder and Maccini 1991; Deloof 2003; García-Teruel and Martinez-Solano 2007; Aktas et al. 2015). Therefore, it is alleged in this paper that the efficient inventory management of the firm is expected to lead to insignificant abnormal inventory (close to the optimal).

\subsubsection{Dependent variables}

Since all the firms in our sample are gathered from the manufacturing industry, the operating margin is used as the main performance measure. ${ }^{4}$ Operating margin has been used extensively in the literature to measure firm performance (Capkun et al. 2009; Deloof and La Rocca 2015; Goto et al. 2015). Operating margin is defined as:

$$
\text { Operating Margin }=\frac{\text { Earnings before interest and taxation }}{\text { Sales }} .
$$

To examine whether trade receivables and trade payables are potential channels through which firms decrease abnormally high inventory or increase abnormally low inventory to improve performance, we included trade receivables and trade payables as dependent variables in separate regressions, respectively. That is, we regressed abnormal inventory on trade receivables and trade payables. As in previous studies (Bougheas et al. 2009; Ferrando and Mulier 2013; Mateut et al. 2015) trade receivables and trade payables are scaled by sales.

\footnotetext{
3 These regressions are not shown but available upon request.

4 In addition to the use of the operating performance, we also assess the robustness of our results by relying on the market measure of excess returns, as presented in Sect. 4.3.4. Our main findings are not sensitive to this choice.
} 


\subsubsection{Econometric specifications and method}

In this paper, we applied the generalised-method-of-moments (GMM) estimators developed for dynamic models of panel data by Arellano and Bond (1991). Our models for operating margin, trade receivables, and trade payables contain three key elements which the GMM estimator is able to accommodate: (1) dynamics in operating margin, trade receivables, and trade payables are captured by the inclusion of their lags; (2) unobserved firm-specific effects; and (3) potential endogeneity concerns. Given the cyclical nature of inventory and following Guariglia (1999), GMM appears to be the better choice for the empirical analyses. In order to eliminate unobserved heterogeneity, we estimate all models in first-difference terms using the one-step GMM estimator and specify the robust estimator of the variance-covariance matrix of the parameters. In all the models, the secondorder correlation (AR2) is not rejected. The use of robust estimator in our GMM models, however, precludes the test for over-identifying restrictions (Gonzalez and González 2008).

To examine the impact of abnormal inventory on performance, trade receivables, and trade payables, we first test the following linear specification:

$$
V_{i t}=\beta_{0}+\beta_{1} \text { Abnormal inventory }{ }_{i, t-1}+\beta_{3} \text { Controls }_{i, t-1}+\varepsilon_{i, t}
$$

where $\boldsymbol{V}$ represents three dependent variables - operating margin, trade receivables, and trade payables. A negative (positive) $\beta_{1}$ coefficient denotes the increase (decrease) in firm performance, trade receivables, or trade payables, as a result of a unit decrease or increase in abnormal inventory across time. Controls denote a set of control variables identified to affect firm performance, trade receivables, and trade payables. $\varepsilon$ is the idiosyncratic error.

To test whether the effect of abnormal inventory on operating performance, trade receivables, or trade payables is nonlinear, this paper also employs the asymmetric model, where the slope coefficient of the regression model is allowed to be separate for abnormally high and abnormally low inventory (see, Aktas et al. 2015). To test this intuition, the following nonlinear specification is used:

$$
\begin{aligned}
V_{i t}= & \beta_{0}+\beta_{1} \text { Abnormal inventory }{ }_{i, t-1} * D \\
& +\beta_{2} \text { Abnormal inventory } \text { Abi } 1-t *(1-D)+\beta_{3} \text { Controls }_{i, t-1}+\varepsilon_{i, t}
\end{aligned}
$$

where $\boldsymbol{D}$ is a dummy variable which denotes value 1 if the corresponding abnormal inventory is high, and 0 for negative.

Following previous studies (e.g. Aktas et al. 2015; Capkun et al. 2009; Mateut et al. 2015; Pong and Mitchell 2012), we control for firm risk, fixed asset growth, research and development (R\&D), firm size, firm age, leverage, and sales growth in the operating margin regressions. For the trade receivables and trade payables regressions, as in previous studies (Afrifa and Gyapong 2017; Hill et al. 2010; Lau and Schaede 2019), we control for firm size, firm age, leverage, sales growth, bank credit, financial distress, and industry concentration. All variables are defined in "Appendix 3".

\subsection{Preliminary analysis}

Table 1 highlights the actual inventory ratio, the predicted inventory ratio, and the abnormal inventory, according to the 14 sub-industries within the manufacturing industry. The results show that the inventory management needs and practices are different from one 


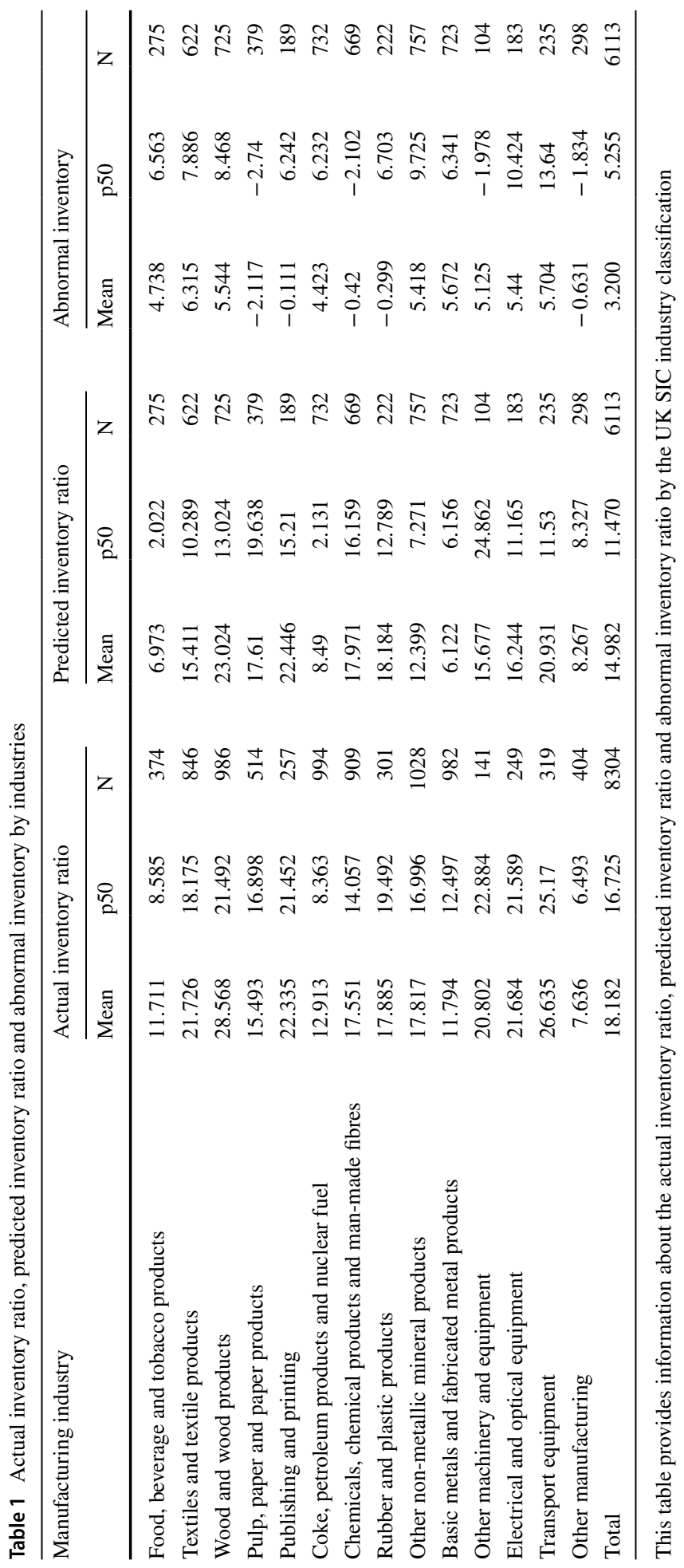


Table 2 Summary statistics

\begin{tabular}{lrrrrrr}
\hline Variable & \multicolumn{1}{c}{ Mean } & \multicolumn{1}{c}{ p10 } & \multicolumn{1}{c}{ p50 } & \multicolumn{1}{l}{ SD } & p90 & N \\
\hline Actual inventory-to-sales (\%) & 18.182 & 6.967 & 16.725 & 15.585 & 52.555 & 8603 \\
Predicted inventory-to-sales (\%) & 14.982 & 5.755 & 11.470 & 16.171 & 50.472 & 6113 \\
Abnormal inventory (\%) & 3.200 & -6.112 & 5.255 & 5.375 & 8.991 & 6113 \\
Abnormally high inventory (\%) & 4.252 & 0.000 & 5.255 & 3.748 & 8.991 & 6113 \\
Abnormally low inventory (\%) & -1.052 & -6.112 & 0.000 & 2.428 & 0.000 & 6113 \\
Operating margin (\%) & 10.133 & 2.247 & 9.213 & 9.379 & 20.536 & 8431 \\
Trade receivables (\%) & 18.393 & 5.872 & 15.827 & 11.003 & 36.432 & 8304 \\
Trade payables (\%) & 26.882 & 23.426 & 27.387 & 3.272 & 28.383 & 8304 \\
Firm risk (\%) & 3.165 & 0.967 & 3.843 & 1.165 & 4.429 & 8297 \\
Fixed asset growth (\%) & 11.252 & 5.800 & 8.840 & 4.627 & 17.603 & 7654 \\
R\&D (\%) & 4.169 & 2.479 & 2.603 & 2.361 & 8.279 & 8156 \\
Total assets (£million) & 389.044 & 17.179 & 386.706 & 154.014 & 1610.254 & 9218 \\
Sales (£million) & 321.467 & 2.831 & 318.303 & 134.000 & 1144.200 & 9218 \\
Firm age & 11.360 & 5.071 & 12.814 & 4.852 & 20.012 & 8294 \\
Leverage (\%) & 12.649 & 0.956 & 8.984 & 12.539 & 31.037 & 8156 \\
Sales growth (\%) & 7.030 & 2.651 & 7.413 & 12.975 & 12.285 & 7645 \\
Bank credit (\%) & 12.204 & 2.087 & 10.815 & 9.908 & 31.759 & 8297 \\
Financial distress (dummy) (\%) & 14.029 & 0.000 & 0.000 & 34.731 & 100.000 & 8304 \\
Sub-industry concentration (\%) & 23.580 & 5.590 & 21.440 & 29.161 & 38.440 & 8291 \\
\hline
\end{tabular}

This table shows the summary statistics for variables used in the regression analysis. All variables are defined in "Appendix 3". All pound values are in millions. $N$ denotes the sample size

sub-industry to another (Gaur et al. 2005). For example, the sub-industry with the highest average actual inventory ratio is wood and wood products with $28.568 \%$, while the other manufacturing industry has the lowest ratio of $7.636 \%$. This underlines the need to determine the optimal inventory ratio of firms according to sub-industry to which they belong. In terms of the average predicted inventory ratio, wood and wood products has the highest ratio of $23.024 \%$, which in comparison with its actual inventory ratio indicates that firms in that sub-industry are operating above the optimal inventory ratio by $5.544 \%$. Also, the subindustry with the lowest average predicted inventory ratio is basic metals and fabricated metal products with $6.122 \%$, which in comparison with the average actual inventory ratio shows that the firms in the sub-industry are operating above the optimal inventory ratio by $5.672 \%$. Finally, the abnormal inventory figures show that 5 out of the 14 industries are operating below the optimal inventory ratio, while the other 9 are operating above the optimal inventory ratio.

The summary statistics presented in Table 2 show that the mean actual inventory ratio is $18.182 \%$, a figure which is very similar to the $18.1 \%, 18.3 \%$, and $19.92 \%$ reported by Pong and Mitchell (2012), Lin and Chou (2015) and Capkun et al. (2009) respectively. The mean predicted inventory ratio of $14.982 \%$ shows that the average firm over-invests in inventory by roughly $3.200 \%$, equating to approximately $£ 10.287$ million of the average 
Table 3 Sample characteristics: abnormally high versus abnormally low inventory

\begin{tabular}{|c|c|c|c|c|c|c|}
\hline \multirow[t]{2}{*}{ Variable } & \multicolumn{2}{|c|}{$\begin{array}{l}\text { Abnormally high } \\
\text { inventory }\end{array}$} & \multicolumn{2}{|c|}{$\begin{array}{l}\text { Abnormally low inven- } \\
\text { tory }\end{array}$} & \multicolumn{2}{|c|}{$\begin{array}{l}p \text { value for abnor- } \\
\text { mally high and } \\
\text { abnormally low }\end{array}$} \\
\hline & Mean & Median & Mean & Median & Mean & Median \\
\hline Operating margin $(\%)$ & 8.660 & 9.176 & 10.345 & 9.203 & 0.000 & 0.000 \\
\hline Trade receivables (\%) & 20.733 & 17.637 & 13.628 & 15.427 & 0.000 & 0.000 \\
\hline Trade payables (\%) & 26.573 & 27.215 & 27.413 & 27.531 & 0.000 & 0.000 \\
\hline Firm risk $(\%)$ & 3.209 & 3.878 & 3.289 & 3.893 & 0.000 & 0.000 \\
\hline Fixed asset growth (\%) & 11.033 & 8.840 & 10.969 & 8.840 & 0.000 & 0.000 \\
\hline $\mathrm{R} \& \mathrm{D}(\%)$ & 3.980 & 2.591 & 4.194 & 2.587 & 0.000 & 0.000 \\
\hline Total assets (£million) & 381.26 & 378.198 & 408.49 & 406.041 & 0.000 & 0.000 \\
\hline Sales (£million) & 321.46 & 309.072 & 334.32 & 331.353 & 0.000 & 0.000 \\
\hline Firm age & 11.327 & 12.842 & 12.351 & 13.465 & 0.262 & 0.099 \\
\hline Leverage (\%) & 13.533 & 9.516 & 11.965 & 7.866 & 0.000 & 0.000 \\
\hline Sales growth (\%) & 7.343 & 7.413 & 7.462 & 7.413 & 0.000 & 0.000 \\
\hline Bank credit (\%) & 24.880 & 21.470 & 23.677 & 20.740 & 0.000 & 0.000 \\
\hline Financial distress (dummy) (\%) & 20.776 & 0.000 & 14.053 & 0.000 & 0.910 & 0.000 \\
\hline Industry concentration (\%) & 13.148 & 10.814 & 7.069 & 8.114 & 0.572 & 0.910 \\
\hline
\end{tabular}

This table compares the sample characteristics of firms with abnormally high and abnormally low inventory. All variables are defined in "Appendix 3". All pound values are in million. For each variable, the last two columns display the $p$ values from a test of mean differences and a test of median differences between abnormally high and abnormally low inventory subsamples, respectively

sales. ${ }^{5}$ Concerning the dependent variables, the mean and median of the operating margin are $10.133 \%$ and $9.213 \%$, respectively. The positive mean and median values suggests, on average, that manufacturing firms in the UK are profitable. The average trade receivables is $18.393 \%$, which shows that approximately $£ 60.092$ million of the average firm's sales is on credit, a non-trivial amount because of the decrease in free cash flow this represents. ${ }^{6}$ The average trade receivable figure of $18.393 \%$ is close to the $21 \%$ by Mian and Smith $\operatorname{Jr}$ (1992). The mean trade payables of the firms in our sample is $26.882 \%$, which is close to the $27 \%$ reported by Deloof and Jegers (1999) and equates to $£ 86.417$ million of sales value. This means that $£ 86.417$ million worth of the average firm’s sales is financed through suppliers' credit, $^{7}$ which supports the findings that suppliers' credit constitutes a major source of credit to firms (Petersen and Rajan 1997; Nilsen 2002; Martínez-Sola et al. 2014; Lin and Chou 2015).

Concerning the control variables, the mean firm risk is $3.165 \%$, which is similar to the $3.89 \%$ reported by Aktas et al. (2015). The average firm has a total assets value of $£ 389.044$ million, which is similar to the $£ 346.941$ million reported by Pong and Mitchell (2012). Bank credit is on average 12.204\%, similar to Deloof and La Rocca's (2015) average value of $14.5 \%$. The descriptive statistics of the other control variables are similar to previous studies.

\footnotetext{
5 Calculated as: $3.200 \% * 321.467$ million.

6 Calculated as: $24.044 \% * 321.467$ million.

7 Calculated as: $23.475 \% * 321.467$ million.
} 
Table 3 reports the summary statistics of the mean and median values of all variables based on abnormally high and low inventory sub-samples. The last two columns display the $p$ values of each variable from a test of differences in mean and median values between the two samples. In contrast to firms with abnormally low inventory, firms with abnormally high inventory have on average inferior operating margin, give out more trade credit to customers, and receive less trade credit from suppliers. It is also interesting to note that the mean and median for the considered control variables are statistically different between firms with abnormally high and abnormally low inventory, except for industry concentration.

Table 4 reports the Pearson's bivariate correlation matrix for the independent variables. The correlations between variables are well below the multicollinearity threshold of $(0.80)$ prescribed by Field (2013). Additionally, we also conduct the variance inflation factor (VIF) to check for the presence of multicollinearity (not reported). The mean VIF value is 1.37 , and they range from 1.04 to 2.11 . The range of the VIF falls far below the conventional threshold of 10 (Gujarati and Porter 2009). Therefore, multicollinearity is not a serious issue for our estimates.

\section{Empirical evidence}

\subsection{Main results}

First, we investigated the relationship between abnormal inventory and firm performance. Second, we investigated whether trade receivables and trade payables are the possible channels via which firms increase or decrease inventory. Finally, we tested if the decrease (increase) of inventory through trade receivables (trade payables) results in higher firm performance.

Table 5 presents the operating performance, trade receivables, and trade payables regressions from Eqs. (2) and (3). Columns (1) and (2) present the operating margin regressions, columns (3) and (4) present the trade receivables regressions, and columns (5) and (6) present the trade payables regressions. The explanatory variable of interest in all columns is abnormal inventory. The lagged operating margin, trade receivables, and trade payables in all columns are positive and statistically significant. This means that previous year's operating margin, trade receivables, and trade payables adjustments do affect the current year's adjustments.

\subsubsection{Abnormal inventory and operating margin}

Column (1) of Table 5 contains the linear regression results from running Eq. (2), which surveys the overall effect of abnormal inventory (both abnormally high and low) on operating margin. The results show that the previous year's abnormal inventory is negatively related to the current year's operating margin. This shows that a decrease in abnormal inventory across time, on average, leads to higher firm performance in the subsequent years. The coefficient estimate of the abnormal inventory is negative and statistically significant $(\beta=-0.255$, t-statistics $=-4.198)$. In particular, an increase of one standard deviation in abnormal inventory is associated with a 15 -percentage point decrease in operating margin. 


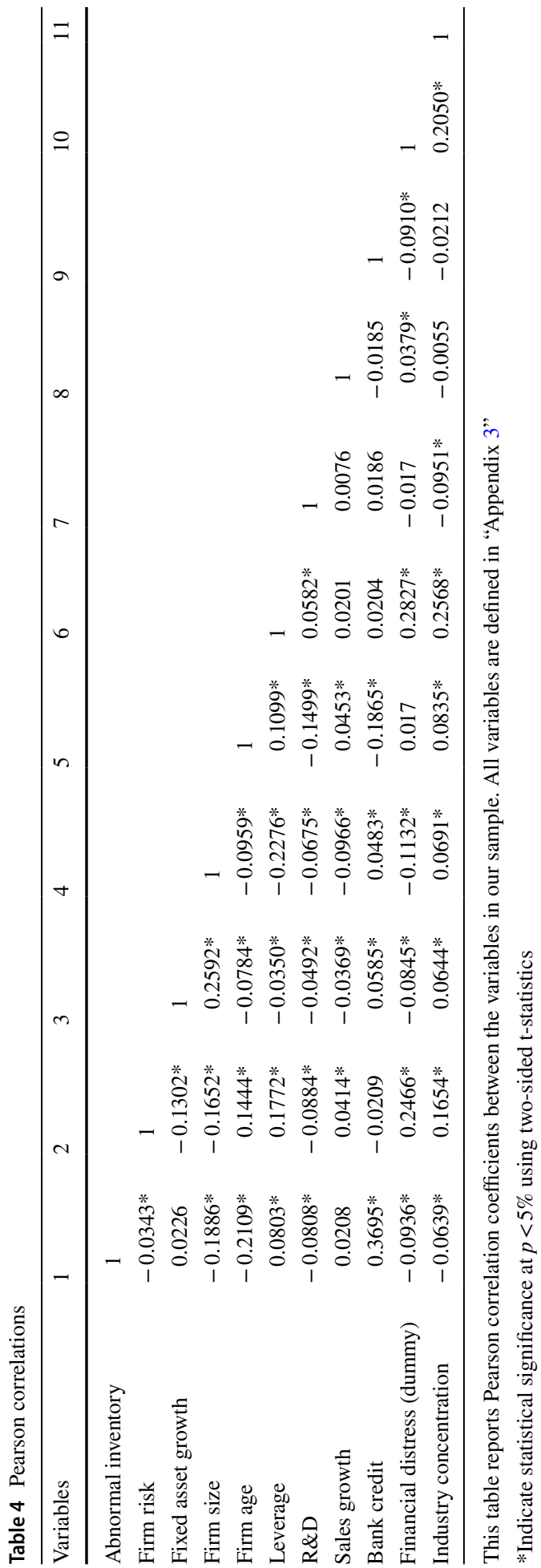


Table 5 Baseline regressions

\begin{tabular}{|c|c|c|c|c|c|c|}
\hline \multirow[t]{2}{*}{ Variables } & \multicolumn{2}{|c|}{ Operating margin } & \multicolumn{2}{|c|}{ Trade receivables } & \multicolumn{2}{|c|}{ Trade payables } \\
\hline & (1) & (2) & (3) & (4) & (5) & (6) \\
\hline $\begin{array}{l}\text { Operating } \\
\text { margin }_{, \mathrm{t}-1}\end{array}$ & $\begin{array}{l}0.672 * * * \\
(18.001)\end{array}$ & $\begin{array}{l}0.659 * * * \\
(18.272)\end{array}$ & & & & \\
\hline $\begin{array}{l}\text { Trade } \\
\quad \text { receivables }, t-1\end{array}$ & & & $\begin{array}{l}0.073 * * * \\
(3.074)\end{array}$ & $\begin{array}{l}0.063 * * * \\
(2.699)\end{array}$ & & \\
\hline Trade payables $_{, t-1}$ & & & & & $\begin{array}{l}0.112^{*} \\
(1.696)\end{array}$ & $\begin{array}{l}0.108 * \\
(1.695)\end{array}$ \\
\hline Abnormal inventory & $\begin{array}{l}-0.255^{* * * *} \\
(-4.198)\end{array}$ & & $\begin{array}{l}-0.657 * * * \\
(-10.769)\end{array}$ & & $\begin{array}{l}0.123 * * * \\
(4.202)\end{array}$ & \\
\hline $\begin{array}{l}\text { Abnormal inven- } \\
\text { tory } \times \mathrm{D}\end{array}$ & & $\begin{array}{l}-0.396^{* * * *} \\
(-5.698)\end{array}$ & & $\begin{array}{l}-0.796 * * * \\
(-11.765)\end{array}$ & & $\begin{array}{l}0.032 \\
(1.266)\end{array}$ \\
\hline $\begin{array}{l}\text { Abnormal inven- } \\
\text { tory } \times(1-D)\end{array}$ & & $\begin{array}{l}0.381 * * * \\
(2.614)\end{array}$ & & $\begin{array}{l}-0.013 \\
(-0.093)\end{array}$ & & $\begin{array}{l}0.539 * * * \\
(5.009)\end{array}$ \\
\hline Firm risk & $\begin{array}{l}0.632 * * * \\
(2.725)\end{array}$ & $\begin{array}{l}0.607 * * * \\
(2.618)\end{array}$ & & & & \\
\hline Fixed asset growth & $\begin{array}{l}-0.053 * * * \\
(-2.671)\end{array}$ & $\begin{array}{l}-0.055^{* * * *} \\
(-2.792)\end{array}$ & & & & \\
\hline $\mathrm{R} \& \mathrm{D}$ & $\begin{array}{l}0.842 * * * \\
(10.402)\end{array}$ & $\begin{array}{l}0.823 * * * \\
(10.390)\end{array}$ & & & & \\
\hline Firm size & $\begin{array}{l}-0.550 \\
(-1.625)\end{array}$ & $\begin{array}{l}-0.484 \\
(-1.415)\end{array}$ & $\begin{array}{l}0.967 * * * \\
(4.463)\end{array}$ & $\begin{array}{l}1.006^{* * *} \\
(4.599)\end{array}$ & $\begin{array}{l}0.489 * * * \\
(3.617)\end{array}$ & $\begin{array}{l}0.510 * * * \\
(3.815)\end{array}$ \\
\hline Age & $\begin{array}{l}-0.241 * * * \\
(-4.162)\end{array}$ & $\begin{array}{l}-0.074 \\
(-1.216)\end{array}$ & $\begin{array}{l}-0.338 * * * \\
(-7.187)\end{array}$ & $\begin{array}{l}-0.163 * * * \\
(-3.251)\end{array}$ & $\begin{array}{l}-0.134 * * * \\
(-3.942)\end{array}$ & $\begin{array}{l}-0.022 \\
(-0.648)\end{array}$ \\
\hline Leverage & $\begin{array}{l}-0.030^{*} \\
(-1.749)\end{array}$ & $\begin{array}{l}-0.037 * * \\
(-2.158)\end{array}$ & $\begin{array}{l}-0.018 \\
(-1.346)\end{array}$ & $\begin{array}{l}-0.026^{*} \\
(-1.880)\end{array}$ & $\begin{array}{l}-0.008 \\
(-0.996)\end{array}$ & $\begin{array}{l}-0.012^{*} \\
(-1.683)\end{array}$ \\
\hline Sales growth & $\begin{array}{l}0.016^{* * * *} \\
(3.447)\end{array}$ & $\begin{array}{l}0.013 * * * \\
(3.338)\end{array}$ & $\begin{array}{l}-0.023 \\
(-1.346)\end{array}$ & $\begin{array}{l}-0.025 \\
(-1.523)\end{array}$ & $\begin{array}{l}-0.030 * * * \\
(-3.378)\end{array}$ & $\begin{array}{l}-0.032 * * * \\
(-3.303)\end{array}$ \\
\hline Bank credit & & & $\begin{array}{l}0.049 * * * \\
(6.238)\end{array}$ & $\begin{array}{l}0.045^{* * * *} \\
(5.838)\end{array}$ & $\begin{array}{l}0.003 \\
(0.951)\end{array}$ & $\begin{array}{l}0.001 \\
(0.173)\end{array}$ \\
\hline $\begin{array}{l}\text { Financial distress } \\
\text { dummy }\end{array}$ & & & $\begin{array}{l}0.005 \\
(1.366)\end{array}$ & $\begin{array}{l}0.007 * * \\
(1.986)\end{array}$ & $\begin{array}{l}0.017 * * * \\
(6.963)\end{array}$ & $\begin{array}{l}0.018 * * * \\
(7.460)\end{array}$ \\
\hline $\begin{array}{l}\text { Industry concentra- } \\
\text { tion }\end{array}$ & & & $\begin{array}{l}0.032 * * \\
(2.068)\end{array}$ & $\begin{array}{l}0.030 * \\
(1.915)\end{array}$ & $\begin{array}{l}0.013 * * * \\
(4.474)\end{array}$ & $\begin{array}{l}0.012 * * * \\
(3.845)\end{array}$ \\
\hline Year & Yes & Yes & Yes & Yes & Yes & Yes \\
\hline Wald $\mathrm{Chi}^{2}$ & $498.25 * * *$ & $527.26 * * *$ & $220.33 * * *$ & $233.79 * * *$ & $146.95 * * *$ & $146.16^{* * *}$ \\
\hline $\mathrm{AR}(1)$ & $-12.548 * * *$ & $-12.573 * * *$ & $-14.115^{* * *}$ & $-14.120 * * *$ & $-12.250 * * *$ & $-12.332 * * *$ \\
\hline $\operatorname{AR}(2)$ & 0.3411 & 0.1075 & 0.8566 & 0.8458 & -0.5694 & -0.6906 \\
\hline $\begin{array}{l}\text { Number of observa- } \\
\text { tions }\end{array}$ & 4476 & 4476 & 4476 & 4476 & 4476 & 4476 \\
\hline
\end{tabular}

This table presents the GMM regressions. The dependent variable is operating margin in columns (1) and (2), trade receivables in columns (3) and (4) and trade payables in columns (5) and (6). The GMM regressions are estimated using the Arellano and Bond (1991) one-step GMM difference estimator for panel data with lagged dependent variables. The linear regressions are displayed in odd numbered columns and nonlinear regressions in even columns. D is a dummy variable taking value one if the corresponding inventory is abnormally high and 0 otherwise. Variable definitions are provided in "Appendix 3"

*Significance at the $10 \%$ level

$* *$ Significance at the $5 \%$ level

$* * *$ Significance at the $1 \%$ level 
Given that firms can have abnormally high or abnormally low inventory, the results obtained in the previous section do not actually tell whether the decrease in abnormal inventory effects on the operating margin is really related to abnormally high or abnormally low inventory. This raises the question as to whether all firms may benefit from a decrease in inventory.

To test this assumption, column (2) reports the asymmetric regression results from running Eq. (3), which surveys the separate effects of abnormally high and abnormally low inventory on firm performance. Two interaction variables are included in the regression model: the first variable, (abnormal inventory* $\boldsymbol{D}$ ), which distinguishes firms with abnormally high inventory, and second, [abnormal inventory* $(1-D)$ ], which identifies firms with abnormally low inventory. The results indicate that the decrease in abnormal inventory over time is positively related with firm performance but only for firms with abnormally high inventory. The coefficient estimation of the first interaction variable (abnormal inventory $\left.{ }^{*} \boldsymbol{D}\right)$ is negative and statistically significant $(\beta=-0.396$, t-statistic $=-5.698)$. In particular, a one standard deviation increase in abnormally high inventory is associated with a 16-percentage point decrease in operating margin. For firms with abnormally low inventory, the second interaction term [abnormal inventory * $(1-\boldsymbol{D})]$ indicates that it is rather an increase in inventory that improves firm performance. The coefficient estimation is positive and statistically significant $(\beta=0.381$, t-statistic $=2.614)$. With regard to economic effect, we find that a one standard deviation increase in abnormally low inventory results in an increase of 10 percentage points in operating margin. Altogether, the asymmetric results show that there is an optimal inventory level, and that firms that are able to converge at this point increase performance.

Concerning the control variables, firm risk, fixed assets growth, $R \& D$, firm age, and leverage are significant at conventional levels. Similar to the literature, firm performance increases with firm risk, $R \& D$, and sales growth, and decreases with fixed assets growth and leverage (Aktas et al. 2015). Firm age is only negative and significant in column (1).

\subsubsection{Abnormal inventory and trade receivables}

So far, the operating margin regressions indicate that firms that are able to decrease (increase) their abnormally high (low) inventory across time enjoy higher performance. Now, the question is, through which channels do firms decrease or increase abnormal inventory which results in higher performance? In columns (3) and (4) of Table 5, the use of trade receivables as the possible avenue through which firms achieve efficient inventory management is explored. Rather than being a liability, firms can actually translate abnormally high inventory into higher firm performance by giving it to customers on credit (Bougheas et al. 2009).

The linear regression results in column (3) show that the coefficient of abnormal inventory is negative and significantly associated with trade receivables $(\beta=-0.657, \mathrm{t}$-statistic $=-10.769$ ), which indicates that a decrease in abnormal inventory across time on average results in higher trade receivables in the next period. The corresponding economic effect is also meaningful: a one standard deviation decrease in abnormal inventory over time is linked with an increase of 32 percentage points in trade receivables over the next period.

Column (4) reports the results of the asymmetric model, which replaces the abnormal inventory with two interactive terms: (abnormal inventory* $\boldsymbol{D}$ ) and [abnormal inventory* $(1-\boldsymbol{D})]$. The dummy variable $\boldsymbol{D}$ identifies firms with abnormally high inventory. 
Therefore, $(1-\boldsymbol{D})$ also identifies firms with abnormally low inventory. Since the linear regression results show that a decrease in abnormal inventory leads to higher trade receivables, it is expected that this decrease originates from the abnormally high inventory. This is because it is wise for a firm with abnormally high inventory to give out more trade credit to customers, so as to reduce the various costs associated with the holding of inventory (Afrifa and Gyapong 2017), to improve the operating cash flows (Aktas et al. 2015) and build good relationships with customers (Long et al. 1993). The results show that only a decrease in abnormally high inventory is associated with trade receivables. Specifically, the coefficient estimate of the interaction variable (abnormal inventory* $\boldsymbol{D}$ ) is negative and statistically significant $(\beta=-0.796$, t-statistic $=-11.765)$ whereas the coefficient estimate of the interaction variable [abnormal inventory* $(1-\boldsymbol{D})$ ] is not statistically significant $(\beta=-0.013$, t-statistic $=-0.093)$. More specifically, the results indicate that firms reduce abnormal inventory through the increase of trade receivables. The corresponding economic effect is meaningful: a one standard deviation decrease in abnormally high inventory is associated with a 27-percentage point increase in trade receivables.

Concerning the control variables, trade receivables increase with firm size, bank credit, and industry concentration, and decrease with firm age. Leverage is only negative and significant in column (4).

\subsubsection{Abnormal inventory and trade payables}

The operating margin regressions indicate that firms which are able to increase abnormally low inventory across time enjoy higher performance. We therefore investigated whether trade payables are the channel through which firms increase abnormally low inventory. Lack of inventory may hamper firm performance through production and trading interruptions (Corsten and Gruen 2004). Trade payables may be the potential channel through which firms increase abnormally low inventory because it allows them to acquire the necessary input without making immediate payment (Nilsen 2002), thus shielding firms from the inefficiencies in the financial market. Trade payables also improve firms' cash flow, allowing investments in profitable opportunities (Aktas et al. 2015). For firms with already abnormally high inventory, increasing inventory is expected to be value decreasing because of the cost of holding inventory. We therefore expect only firms with abnormally low inventory to benefit from an increase of inventory through trade payables.

The results of the trade payables regressions are presented in columns (5) and (6) of Table 5. Column (5) shows the results of the linear regression results. The coefficient of abnormal inventory is significantly associated with trade payables $(\beta=0.123$, t-statistic $=4.202$ ), which indicates that an increase in abnormal inventory across time, on average, results in higher trade payables in the next period. With regard to economic effect, we find that a one standard deviation increase in abnormal inventory across time is linked with an increase of 20 percentage points in trade payables over the next period.

Column (6) reports the results of the asymmetric model, which replaces the abnormal inventory with two interactive terms, including (abnormal inventory $\times \boldsymbol{D}$ ) and [abnormal inventory $\times(1-\boldsymbol{D})]$. The dummy variable $\boldsymbol{D}$ identifies firms with abnormally high inventory. Therefore, $(1-\boldsymbol{D})$ also identifies firms with abnormally low inventory. Since the linear regression results show that an increase in abnormal inventory leads to higher trade payables, we expect this increase to originate from the abnormally low inventory. This is because firms with abnormally low inventory are expected to benefit from suppliers' credit by replenishing inventory, therefore avoiding any potential stock-out situation. The results 
show that only an increase in abnormally low inventory is associated with trade payables. Specifically, the coefficient estimate of the interaction variable (abnormal inventory $\times \boldsymbol{D}$ ) is not statistically significant $(\beta=0.032$, $t$-statistic $=1.266$ ); however, the interaction variable [abnormal inventory $\times(1-\boldsymbol{D})]$ is positive and statistically significant $(\beta=0.539$, t-statistic $=5.009$ ). The corresponding economic effects are also meaningful: a one standard deviation increase in abnormally low inventory is associated with a 40-percentage point increase in trade payables.

\subsubsection{Interaction effect of trade receivables and trade payables on abnormal inventory-performance relationship}

So far, the results in Table 5 show that abnormal inventory affects firm performance and that firms decrease (increase) their abnormally high (low) inventory through trade receivables (trade payables). This section therefore provides the link to show whether the higher performance of the decrease (increase) in abnormally high (low) inventory results from an increase in trade receivables (trade payables). To do this, we expanded Eqs. (2) and (3) by the inclusion of interaction variables. Abnormal inventory is interacted with trade receivables and payables in columns (1) and (3) respectively. In columns (2) and (4), [abnormal inventory $\times \boldsymbol{D}$ ] and [abnormal inventory $\times(1-\boldsymbol{D})$ ] are interacted with trade receivables and trade payables respectively. The results are contained in Table 6 .

In column (1), the main variable of interest, [abnormal inventory $\times$ trade credit], is positive and statistically significant $(\beta=0.021$, $\mathrm{t}$-statistics $=5.122)$. This indicates that, for firms with abnormal inventory, an increase in trade receivables leads to higher firm performance. However, this does not tell whether the positive association is as a result of a decrease in abnormally high or abnormally low inventory. In column (2), the interaction variable [abnormal inventory $\times \boldsymbol{D} \times$ trade receivables] is high and statistically significant $(\beta=0.015$, t-statistics $=2.759$ ). This shows that, for firms with abnormally high inventory, an increase in trade receivables leads to higher firm performance, supporting hypotheses (1) and (2). The interaction variable [abnormal inventory $\times(1-\boldsymbol{D}) \times$ trade receivables] is, however, not statistically significant $(\beta=0.019$, t-statistics $=1.405)$. This shows that changes in trade receivables do not affect the performance of firms with abnormally low inventory.

The results in column (3) show that the interaction variable (abnormal inventory $\times$ trade payables) is not statistically significant $(\beta=0.196$, $t$-statistics $=0.302)$. Next, we show the results of the interaction variables' [abnormal inventory $\times \boldsymbol{D} \times$ trade payables] and [abnormal inventory $\times(1-\boldsymbol{D}) \times$ trade payables] effect on performance in column (4). The results show that only the interaction variable [abnormal inventory $\times(1-\boldsymbol{D}) \times$ trade payables] has a significant association with performance $(\beta=0.043$, t-statistics $=1.987)$. More specifically, the results show that for firms with abnormally low inventory, an increase in trade payables leads to higher performance, which support hypotheses (1) and (3). The interaction variable [abnormal inventory $\times \boldsymbol{D} \times$ trade receivables] is not statistically significant $(\beta=-0.022$, t-statistics $=-0.958)$. Overall, the results in this section support our earlier results presented in Table 5, that firms with abnormally high (low) inventory can improve operating performance through trade receivables (trade payables).

Although our study covers the period before the Brexit referendum, it offers important insights into the effect of the increase in the level of inventories, associated with Brexit uncertainty, on firm performance. The Brexit uncertainty and the fears about departing the EU without a deal had a great impact on the manufacturing sector in the UK. According to a report published by the Office for National Statistics, manufacturing reached its highest 
Table 6 Interaction effect of trade receivables and trade payables on abnormal inventory-performance relationship

\begin{tabular}{|c|c|c|c|c|}
\hline Variables & (1) & (2) & (3) & (4) \\
\hline Operatitng margin $_{, t-1}$ & $\begin{array}{l}0.660 * * * \\
(18.228)\end{array}$ & $\begin{array}{l}0.654 * * * \\
(18.325)\end{array}$ & $\begin{array}{l}0.666^{* * * *} \\
(17.859)\end{array}$ & $\begin{array}{l}0.653 * * * \\
(18.081)\end{array}$ \\
\hline Abnormal inventory & $\begin{array}{l}-0.601 * * * \\
(-5.974)\end{array}$ & & $\begin{array}{l}-0.532 * \\
(-1.815)\end{array}$ & \\
\hline Abnormal inventory $\times$ trade receivables & $\begin{array}{l}0.021 * * * \\
(5.122)\end{array}$ & & & \\
\hline Abnormal inventory $\times$ trade payables & & & $\begin{array}{l}0.196 \\
(0.302)\end{array}$ & \\
\hline Abnormal inventory $\times \mathrm{D}$ & & $\begin{array}{l}-0.259 \\
(-0.580)\end{array}$ & & $\begin{array}{l}-0.890 \\
(-1.621)\end{array}$ \\
\hline Abnormal inventory $\times(1-D)$ & & $\begin{array}{l}0.056^{*} \\
(1.896)\end{array}$ & & $\begin{array}{l}0.064 * \\
(1.743)\end{array}$ \\
\hline Trade receivables & $\begin{array}{l}0.459 * * * \\
(6.826)\end{array}$ & $\begin{array}{l}0.572 * * * \\
(4.918)\end{array}$ & & \\
\hline Abnormal inventory $\times \mathrm{D} \times$ trade receivables & & $\begin{array}{l}0.015^{* * *} \\
(2.759)\end{array}$ & & \\
\hline Abnormal inventory $\times(1-D) \times$ trade receivables & & $\begin{array}{l}0.019 \\
(1.405)\end{array}$ & & \\
\hline Trade payables & & & $\begin{array}{l}0.008 \\
(0.775)\end{array}$ & $\begin{array}{l}-0.557 * * * \\
(-4.838)\end{array}$ \\
\hline Abnormal inventory $\times \mathrm{D} \times$ trade payables & & & & $\begin{array}{l}-0.022 \\
(-0.958)\end{array}$ \\
\hline Abnormal inventory $\times(1-D) \times$ trade payables & & & & $\begin{array}{l}0.043 * * \\
(1.987)\end{array}$ \\
\hline Firm risk & $\begin{array}{l}0.629 * * * \\
(2.704)\end{array}$ & $\begin{array}{l}0.619 * * * \\
(2.654)\end{array}$ & $\begin{array}{l}0.497 * * \\
(2.212)\end{array}$ & $\begin{array}{l}0.483^{* *} \\
(2.152)\end{array}$ \\
\hline Fixed asset growth & $\begin{array}{l}-0.050^{* *} \\
(-2.532)\end{array}$ & $\begin{array}{l}-0.051 * * * \\
(-2.586)\end{array}$ & $\begin{array}{l}-0.043^{* *} \\
(-2.240)\end{array}$ & $\begin{array}{l}-0.045^{* *} \\
(-2.361)\end{array}$ \\
\hline $\mathrm{R} \& \mathrm{D}$ & $\begin{array}{l}0.839 * * * \\
(10.575)\end{array}$ & $\begin{array}{l}0.829 * * * \\
(10.476)\end{array}$ & $\begin{array}{l}0.693 * * * \\
(9.050)\end{array}$ & $\begin{array}{l}0.665^{\text {*** }} \\
(8.481)\end{array}$ \\
\hline Firm size & $\begin{array}{l}-0.605^{*} \\
(-1.791)\end{array}$ & $\begin{array}{l}-0.576^{*} \\
(-1.687)\end{array}$ & $\begin{array}{l}-0.733 * * \\
(-2.158)\end{array}$ & $\begin{array}{l}-0.669 * \\
(-1.946)\end{array}$ \\
\hline Age & $\begin{array}{l}-0.134 * * \\
(-2.364)\end{array}$ & $\begin{array}{l}-0.063 \\
(-1.035)\end{array}$ & $\begin{array}{l}-0.192 * * * \\
(-3.335)\end{array}$ & $\begin{array}{l}-0.058 \\
(-0.945)\end{array}$ \\
\hline Leverage & $\begin{array}{l}-0.037 * * \\
(-2.190)\end{array}$ & $\begin{array}{l}-0.039 * * \\
(-2.285)\end{array}$ & $\begin{array}{l}-0.034 * * \\
(-1.985)\end{array}$ & $\begin{array}{l}-0.038 * * \\
(-2.271)\end{array}$ \\
\hline Sales growth & $\begin{array}{l}0.014 * * \\
(2.523)\end{array}$ & $\begin{array}{l}0.014 * * \\
(2.552)\end{array}$ & $\begin{array}{l}0.028 * * * \\
(3.728)\end{array}$ & $\begin{array}{l}0.024 \text { *** } \\
(3.425)\end{array}$ \\
\hline Year & Yes & Yes & Yes & Yes \\
\hline Wald $\mathrm{Chi}^{2}$ & $533.69 * * *$ & $545.26 * * *$ & $529.65 * * *$ & $557.66 * * *$ \\
\hline $\mathrm{AR}(1)$ & $-12.545^{* * *}$ & $-12.543 * * *$ & $-12.62 * * *$ & $-12.612 * * *$ \\
\hline $\mathrm{AR}(2)$ & 0.248 & 0.045 & 0.267 & -0.006 \\
\hline Number of observations & 4476 & 4476 & 4476 & 4476 \\
\hline
\end{tabular}

This table presents the GMM regressions. The dependent variable is operating margin in all columns. The GMM regressions are estimated using the Arellano and Bond (1991) one-step GMM difference estimator for panel data with lagged dependent variables. The linear regressions are displayed in odd numbered columns and non-linear regressions in even columns. D is a dummy variable taking value one if the corresponding inventory is abnormally high and 0 otherwise. Variable definitions are provided in "Appendix 3 "

*Significance at the $10 \%$ level

**Significance at the $5 \%$ level

$* * *$ Significance at the $1 \%$ level 
level in February 2019 since the global financial crisis in 2008 (Office for National Statistics 2019a). This is because both small and big manufacturers have increased their finished goods and stockpiled raw materials and components that go into their products (Pfeifer 2019). As a result, many small and medium-sized manufacturers face cash-flow problems and may go out of business (Pooler 2019). Based on our results, firms can enjoy higher performance when they decrease their abnormally high inventory via trade receivables. The European customers of UK manufacturers increased their purchases in the first quarter of 2019, but they are likely to decrease their purchases through the rest of the year (Pfeifer 2019). Therefore, UK manufacturers should reduce their manufacturing and control stockpiling of raw materials as they may not be able to reduce all excess inventories through the receivables channel. At the same time, they are less likely to benefit from the payables channel as they have already stockpiled raw materials and components of goods.

Consistent with our results, a more recent report by the Office for National Statistics revealed a long-term weakening in both production and manufacturing (Office for National Statistics 2019b). The impact of Brexit uncertainty on supply chains, however, would not finish with the departure from the EU. According to Gysegom et al. (2019), "Brexit poses major uncertainty for supply chains — and this could persist for a decade or more" (p. 3). As such, UK manufacturers need to rethink their supply-chain strategies and adjust their inventory levels as the abnormally high level of inventory has negative impact on firm performance.

\subsection{Further analysis}

Firm risk could be the possible alternative explanation for the increase in operating performance from a decrease (increase) in abnormally high (low) inventory. A decrease in inventory can intensify the risk faced by firms (Aktas et al. 2015) from loss of sales due to stockouts (Blinder and Maccini, 1991; Corsten and Gruen 2004). Alternatively, an increase in inventory can exaggerate the risk to the firm potentially resulting in bankruptcy (Shin and Soenen 1998) because of the strain on cash flows. Consequently, the negative (positive) association between decrease (increase) of abnormally high (low) inventory and operating performance may be caused by the increase in firm risk after a decrease or increase in inventory. To gauge if the firm risk channel steers the performance results, firm risk is regressed on abnormal inventory. Table 7 reports the results. Firm risk is measured as the standard deviation of daily stock return (Aktas et al. 2015).

In all columns, the dependent variable is firm risk and the explanatory variable of interest is abnormal inventory. Column (1) displays the linear regression results, while column (2) presents the asymmetric model estimation results. According to the linear model results in column (1), abnormal inventory is positively associated with firm risk ( $\beta=0.032$, t-statistic $=5.501$ ). This shows that an increase in abnormal inventory across time increases firm risk in the following period. On the other hand, the asymmetric model estimation results in column (2) indicate that the positive association between abnormal inventory and firm risk is caused by firms with abnormally high inventory $(\beta=0.053$, t-statistic $=9.450)$. This finding means that for firms with already abnormally high inventory, a further increase in inventory increases risk.

For firms with abnormally low inventory, the association between abnormal inventory and firm risk is negative and statistically significant $(\beta=-0.043$, t-statistic $=-2.694)$. This finding shows that for firms with already abnormally low inventory, a further reduction in inventory increases risk. The positive (negative) effect of abnormally high (low) inventory 
Table 7 Abnormal inventory and firm risk

\begin{tabular}{|c|c|c|}
\hline Variables & (1) & (2) \\
\hline Firm risk $_{, t-1}$ & $\begin{array}{l}0.252 * * * \\
(8.203)\end{array}$ & $\begin{array}{l}0.245^{* * * *} \\
(7.945)\end{array}$ \\
\hline Abnormal inventory & $\begin{array}{l}0.032 * * * \\
(5.501)\end{array}$ & \\
\hline Abnormal inventory $\times D$ & & $\begin{array}{l}0.053 * * * \\
(9.450)\end{array}$ \\
\hline Abnormal inventory $\times(1-D)$ & & $\begin{array}{l}-0.043 * * * \\
(-2.694)\end{array}$ \\
\hline Fixed asset growth & $\begin{array}{l}-0.006 * * * \\
(-3.445)\end{array}$ & $\begin{array}{l}-0.006^{* * * *} \\
(-3.252)\end{array}$ \\
\hline Firm size & $\begin{array}{l}0.769 * * * \\
(14.251)\end{array}$ & $\begin{array}{l}0.753 * * * \\
(13.942)\end{array}$ \\
\hline Age & $\begin{array}{l}-0.011 * * \\
(-2.243)\end{array}$ & $\begin{array}{l}-0.031 * * * \\
(-4.894)\end{array}$ \\
\hline Leverage & $\begin{array}{l}0.007 * * * \\
(5.388)\end{array}$ & $\begin{array}{l}0.008 * * * \\
(5.986)\end{array}$ \\
\hline Sales growth & $\begin{array}{l}-0.002 \\
(-1.090)\end{array}$ & $\begin{array}{l}-0.001 \\
(-0.817)\end{array}$ \\
\hline Book to market & $\begin{array}{l}-30.468 * * * \\
(-14.215)\end{array}$ & $\begin{array}{l}-33.304 * * * \\
(-15.516)\end{array}$ \\
\hline Year & Yes & Yes \\
\hline Wald $\mathrm{Chi}^{2}$ & $1255.20 * * *$ & $1273.49 * * *$ \\
\hline $\mathrm{AR}(1)$ & $-10.258 * * *$ & $-10.081 * * *$ \\
\hline $\mathrm{AR}(2)$ & 0.0135 & 0.0551 \\
\hline Observations & 4476 & 4476 \\
\hline
\end{tabular}

This table presents the GMM firm risk regressions. The dependent variable is firm risk in all columns. The GMM regressions are estimated using the Arellano and Bond (1991) one-step GMM difference estimator for panel data with lagged dependent variables. The linear regression is displayed in column (1) and non-linear regression in column (2). D is a dummy variable taking value one if the corresponding inventory is abnormally high and 0 otherwise. Variable definitions are provided in "Appendix 3"

**Significance at the $5 \%$ level

$* * *$ Significance at the $1 \%$ level

and firm risk indicates that firms with abnormally high or abnormally low inventory need to reduce and increase inventory, respectively, thus reducing risk. This summarises our main results and rules out the risk channel as a possible reason for the negative (positive) association between firm performance and abnormally high (low) inventory.

\subsection{Robustness tests}

In this paper, we conduct several tests to control for the possibility of the results in Table 5 being influenced by other external factors. 


\subsubsection{Changes in variables}

Prior studies suggest the possibility of a firm's strategic choices simultaneously influencing both inventory and performance (Mendelson and Parlaktürk 2008). It is therefore possible for a third factor to affect both abnormal inventory and better operating performance. For example, an increased demand from customers would lead to both lower inventory and better performance. Conversely, a firm that positions itself to provide customers with high-quality service may hold higher inventory, resulting in a positive relationship between inventory and operating performance. To control for these factors, we use the changes in (other than the level of) operating margin, abnormal inventory, trade receivables, and trade payables. The sign $(\Delta)$ represents a change in the variable as displayed in Table 8. By using the changes in variables over time, any results obtained show that the associations persist over time between firms and within the same strategy (Capkun et al. 2009). Using the changes in variables sacrifices the first observation for each firm, and therefore reduces the number of observations.

The use of changes in variables produced qualitatively similar results. Change in abnormally high inventory has a negative and statistically significant association with change in operating margin $(\beta=-0.006$, t-statistic $=-2.166)$. Regarding the change in abnormally low inventory, the results show a positive relationship with change in operating margin $(\beta=0.007$, t-statistic $=2.099)$. In addition, change in abnormally high inventory is negative and statistically related with change in trade receivables $(\beta=-0.001$, $t$-statistic $=-1.902)$ whereas change in abnormally low inventory is positive and statistically associated with change in trade payables $(\beta=0.010$, t-statistic $=2.233)$.

\subsubsection{Sales surprises}

Moreover, the relationships could be influenced by sales surprises (Capkun et al. 2009). That is, a firm that misses (exceeds) sales targets will have higher (lower) inventory accumulation and (lower) higher performance. According to Banker et al. (2019), managers struggle to dispose of excess inventory in the face of decrease in demand. We control for these possibilities by using the quarterly data (in addition to the annual data) for analysing the abnormal inventory association with operating margin, trade receivables, and trade payables relationships. This leads to 40 quarterly data sets ( 4 quarters $\times 10$ years), which reduces the possibility of any sales surprise in a given quarter having an impact on the effect of abnormal inventory on firm performance, trade receivables, and trade payables. This procedure is the same as in Capkun et al. (2009).

The results displayed in Table 9 are comparatively similar to the results presented in Table 5 and indicate that the previous assertions still hold. For the linear regression results, abnormal inventory is negative (positive) and statistically significant with operating margin and trade receivables (trade payables). Regarding the asymmetry regression results, the coefficients of abnormally high (low) inventory is negative (positive) and statistically associated with operating margin and trade receivables (operating margin and trade payables).

\subsubsection{Industry mean-adjusted abnormal inventory}

So far, the estimation of the abnormal inventory has relied on a regression-based approach. To further assess the robustness of the main findings, the industry mean-adjusted abnormal inventory is used in Table 10. The industry mean-adjusted abnormal inventory for a given 
Table 8 Change in variables

\begin{tabular}{|c|c|c|c|c|c|c|}
\hline \multirow[t]{2}{*}{ Variables } & \multicolumn{2}{|c|}{ Operating margin } & \multicolumn{2}{|c|}{ Trade receivables } & \multicolumn{2}{|c|}{ Trade payables } \\
\hline & (1) & (2) & (3) & (4) & (5) & (6) \\
\hline$\Delta$ Operating margin $_{, \mathrm{t}-1}$ & $\begin{array}{l}-0.052 * * * \\
(-3.049)\end{array}$ & $\begin{array}{l}-0.051 * * * \\
(-3.007)\end{array}$ & & & & \\
\hline$\Delta$ Trade receivables $_{, t-1}$ & & & $\begin{array}{l}-0.014 * * * \\
(-3.251)\end{array}$ & $\begin{array}{l}-0.014 * * * \\
(-3.250)\end{array}$ & & \\
\hline$\Delta$ Trade payables $_{, \mathrm{t}-1}$ & & & & & $\begin{array}{l}-0.036 \\
(-1.421)\end{array}$ & $\begin{array}{l}-0.036 \\
(-1.421)\end{array}$ \\
\hline$\Delta$ Abnormal inventory & $\begin{array}{l}-0.004 \\
(-1.441)\end{array}$ & & $\begin{array}{l}-0.000 * * \\
(-2.066)\end{array}$ & & $\begin{array}{l}0.001 \\
(0.610)\end{array}$ & \\
\hline $\begin{array}{l}\Delta \text { Abnormal inven- } \\
\text { tory } \times \mathrm{D}\end{array}$ & & $\begin{array}{l}-0.006 * * \\
(-2.166)\end{array}$ & & $\begin{array}{l}-0.001^{*} \\
(-1.902)\end{array}$ & & $\begin{array}{l}-0.000 \\
(-0.084)\end{array}$ \\
\hline $\begin{array}{l}\Delta \text { Abnormal inven- } \\
\text { tory } \times(1-\mathrm{D})\end{array}$ & & $\begin{array}{l}0.007 * * \\
(2.099)\end{array}$ & & $\begin{array}{l}-0.000 \\
(-0.916)\end{array}$ & & $\begin{array}{l}0.010 * * \\
(2.233)\end{array}$ \\
\hline Firm risk & $\begin{array}{l}0.170 \\
(1.252)\end{array}$ & $\begin{array}{l}0.161 \\
(1.190)\end{array}$ & & & & \\
\hline Fixed asset growth & $\begin{array}{l}-0.017^{*} \\
(-1.923)\end{array}$ & $\begin{array}{l}-0.017^{*} \\
(-1.818)\end{array}$ & & & & \\
\hline $\mathrm{R} \& \mathrm{D}$ & $\begin{array}{l}-0.132 \\
(-0.595)\end{array}$ & $\begin{array}{l}-0.127 \\
(-0.570)\end{array}$ & $\begin{array}{l}0.008 \\
(0.735)\end{array}$ & $\begin{array}{l}0.008 \\
(0.735)\end{array}$ & $\begin{array}{l}-0.078 \\
(-0.455)\end{array}$ & $\begin{array}{l}-0.081 \\
(-0.468)\end{array}$ \\
\hline Firm size & $\begin{array}{l}-0.026 \\
(-1.007)\end{array}$ & $\begin{array}{l}-0.023 \\
(-0.896)\end{array}$ & $\begin{array}{l}-0.006 * * * \\
(-3.661)\end{array}$ & $\begin{array}{l}-0.006^{* * * *} \\
(-3.671)\end{array}$ & $\begin{array}{l}-0.168 * * \\
(-2.108)\end{array}$ & $\begin{array}{l}-0.167 * * \\
(-2.085)\end{array}$ \\
\hline Age & $\begin{array}{l}0.002 \\
(0.245)\end{array}$ & $\begin{array}{l}0.002 \\
(0.280)\end{array}$ & $\begin{array}{l}-0.000 \\
(-0.216)\end{array}$ & $\begin{array}{l}-0.000 \\
(-0.216)\end{array}$ & $\begin{array}{l}0.075^{*} \\
(1.730)\end{array}$ & $\begin{array}{l}0.076^{*} \\
(1.733)\end{array}$ \\
\hline Leverage & $\begin{array}{l}0.186^{* * * *} \\
(5.000)\end{array}$ & $\begin{array}{l}0.185^{* * *} * \\
(4.965)\end{array}$ & & & & \\
\hline Sales growth & $\begin{array}{l}-0.004 * * \\
(-2.179)\end{array}$ & $\begin{array}{l}-0.004 * * \\
(-2.208)\end{array}$ & $\begin{array}{l}-0.001 \\
(-1.439)\end{array}$ & $\begin{array}{l}-0.001 \\
(-1.439)\end{array}$ & $\begin{array}{l}0.002 \\
(0.301)\end{array}$ & $\begin{array}{l}0.001 \\
(0.299)\end{array}$ \\
\hline Bank credit & & & $\begin{array}{l}0.000 * * \\
(2.154)\end{array}$ & $\begin{array}{l}0.000 * * \\
(2.152)\end{array}$ & $\begin{array}{l}-0.008^{*} \\
(-1.938)\end{array}$ & $\begin{array}{l}-0.008^{*} \\
(-1.950)\end{array}$ \\
\hline $\begin{array}{l}\text { Financial distress } \\
\text { dummy }\end{array}$ & & & $\begin{array}{l}0.001 * * \\
(2.296)\end{array}$ & $\begin{array}{l}0.001 * * \\
(2.296)\end{array}$ & $\begin{array}{l}0.005 \\
(0.523)\end{array}$ & $\begin{array}{l}0.005 \\
(0.520)\end{array}$ \\
\hline Industry concentration & & & $\begin{array}{l}0.003^{* * *} * \\
(4.089)\end{array}$ & $\begin{array}{l}0.003 * * * \\
(4.087)\end{array}$ & $\begin{array}{l}-0.057 * * * \\
(-8.213)\end{array}$ & $\begin{array}{l}-0.057 * * * \\
(-8.188)\end{array}$ \\
\hline Year & Yes & Yes & Yes & Yes & Yes & Yes \\
\hline Wald $\mathrm{Chi}^{2}$ & $57.01 * * *$ & $65.31 * * *$ & $67.63 * * *$ & $67.96 * * *$ & $127.02 * * *$ & $129.76^{* * *}$ \\
\hline AR (1) & $-9.695 * * *$ & $-9.631 * * *$ & $-18.163 * * *$ & $-18.151 * * *$ & -1.051 & -1.049 \\
\hline $\operatorname{AR}(2)$ & -0.1265 & -0.0627 & -0.9676 & -0.9671 & -0.9418 & -0.9440 \\
\hline $\begin{array}{l}\text { Number of observa- } \\
\text { tions }\end{array}$ & 3951 & 3951 & 3951 & 3951 & 3951 & 3951 \\
\hline
\end{tabular}

This table presents the changes in dependent and explanatory variables GMM regressions. The dependent variable is $\left(\right.$ EBIT - EBIT $\left._{t-1}\right) /$ sales $_{t-1}$ in columns (1) and (2), (receivables - receivables t $\left._{t-1}\right) /$ sales $_{t-1}$ in columns (3) and (4) and (payables - payables $_{t-1}$ )/sales $\mathrm{s}_{\mathrm{t}-1}$ in columns (5) and (6). The GMM regressions are estimated using the Arellano and Bond (1991) one-step GMM difference estimator for panel data with lagged dependent variables. The linear regressions are displayed in odd numbered columns and non-linear regressions in even columns. D is a dummy variable taking value one if the corresponding inventory is abnormally high and 0 otherwise. Variable definitions are provided in "Appendix 3"

*Significance at the $10 \%$ level

$* *$ Significance at the $5 \%$ level

***Significance at the $1 \%$ level 
Table 9 Sales surprises effect

\begin{tabular}{|c|c|c|c|c|c|c|}
\hline & \multicolumn{2}{|c|}{ Operating margin } & \multicolumn{2}{|c|}{ Trade receivables } & \multicolumn{2}{|c|}{ Trade payables } \\
\hline & (1) & (2) & (3) & (4) & (5) & (6) \\
\hline $\begin{array}{l}\text { Operating } \\
\text { margin }_{, \mathrm{t}-1}\end{array}$ & $\begin{array}{l}0.620 * * * \\
(36.80)\end{array}$ & $\begin{array}{l}0.609 * * * \\
(36.78)\end{array}$ & & & & \\
\hline $\begin{array}{l}\text { Trade } \\
\quad \text { receivables }_{, \mathrm{t}-1}\end{array}$ & & & $\begin{array}{l}0.446 * * * \\
(28.35)\end{array}$ & $\begin{array}{l}0.443 * * * \\
(28.18)\end{array}$ & & \\
\hline Trade payables $_{, t-1}$ & & & & & $\begin{array}{l}0.577 * * * \\
(21.14)\end{array}$ & $\begin{array}{l}0.565^{* * * *} \\
(20.78)\end{array}$ \\
\hline Abnormal inventory & $\begin{array}{l}-0.490 * * * \\
(-5.16)\end{array}$ & & $\begin{array}{l}-0.703^{* * * *} \\
(-8.74)\end{array}$ & & $\begin{array}{l}0.104 * * \\
(2.19)\end{array}$ & \\
\hline $\begin{array}{l}\text { Abnormal inven- } \\
\text { tory } \times D\end{array}$ & & $\begin{array}{l}-0.801 * * * \\
(-7.19)\end{array}$ & & $\begin{array}{l}-0.876^{* * * *} \\
(-9.41)\end{array}$ & & $\begin{array}{l}-0.036 \\
(-0.83)\end{array}$ \\
\hline $\begin{array}{l}\text { Abnormal inven- } \\
\text { tory } \times(1-D)\end{array}$ & & $\begin{array}{l}0.822 * * * \\
(4.01)\end{array}$ & & $\begin{array}{l}0.059 \\
(0.32)\end{array}$ & & $\begin{array}{l}0.699 * * * \\
(3.92)\end{array}$ \\
\hline Firm risk & $\begin{array}{l}1.389 * * * \\
(3.60)\end{array}$ & $\begin{array}{l}1.395 * * * \\
(3.58)\end{array}$ & & & & \\
\hline Fixed asset growth & $\begin{array}{l}-0.070^{* *} \\
(-2.41)\end{array}$ & $\begin{array}{l}-0.071 * * \\
(-2.42)\end{array}$ & & & & \\
\hline $\mathrm{R} \& \mathrm{D}$ & $\begin{array}{l}1.610 * * * \\
(10.74)\end{array}$ & $\begin{array}{l}1.590 * * * \\
(10.76)\end{array}$ & & & & \\
\hline Firm size & $\begin{array}{l}-1.469 * * * \\
(-2.73)\end{array}$ & $\begin{array}{l}-1.415^{* * *} \\
(-2.62)\end{array}$ & $\begin{array}{l}-3.123 * * * \\
(-6.64)\end{array}$ & $\begin{array}{l}-3.107 * * * \\
(-6.64)\end{array}$ & $\begin{array}{l}1.302^{* * * *} \\
(5.71)\end{array}$ & $\begin{array}{l}1.318^{* * * *} \\
(5.81)\end{array}$ \\
\hline Age & $\begin{array}{l}-0.378 * * * \\
(-4.03)\end{array}$ & $\begin{array}{l}-0.035 \\
(-0.37)\end{array}$ & $\begin{array}{l}-0.116^{*} \\
(-1.70)\end{array}$ & $\begin{array}{l}0.087 \\
(1.05)\end{array}$ & $\begin{array}{l}-0.200 * * * \\
(-3.88)\end{array}$ & $\begin{array}{l}-0.041 \\
(-0.69)\end{array}$ \\
\hline Leverage & $\begin{array}{l}-0.059 * * \\
(-2.26)\end{array}$ & $\begin{array}{l}-0.074 * * * \\
(-2.87)\end{array}$ & $\begin{array}{l}0.040 \\
(1.29)\end{array}$ & $\begin{array}{l}0.031 \\
(0.99)\end{array}$ & $\begin{array}{l}-0.026^{*} \\
(-1.87)\end{array}$ & $\begin{array}{l}-0.033 * * \\
(-2.44)\end{array}$ \\
\hline Sales growth & $\begin{array}{l}-0.025 \\
(-0.40)\end{array}$ & $\begin{array}{l}0.001 \\
(0.02)\end{array}$ & $\begin{array}{l}-0.038 \\
(-0.56)\end{array}$ & $\begin{array}{l}-0.027 \\
(-0.40)\end{array}$ & $\begin{array}{l}-0.056^{* *} \\
(-2.02)\end{array}$ & $\begin{array}{l}-0.049 * \\
(-1.76)\end{array}$ \\
\hline Bank credit & & & $\begin{array}{l}0.056^{* * * *} \\
(3.34)\end{array}$ & $\begin{array}{l}0.051 * * * \\
(3.04)\end{array}$ & $\begin{array}{l}-0.014 * * \\
(-2.06)\end{array}$ & $\begin{array}{l}-0.018 * * * \\
(-2.68)\end{array}$ \\
\hline $\begin{array}{l}\text { Financial distress } \\
\text { dummy }\end{array}$ & & & $\begin{array}{l}-1.623 * * * \\
(-2.63)\end{array}$ & $\begin{array}{l}-1.403 * * \\
(-2.26)\end{array}$ & $\begin{array}{l}0.616^{*} \\
(1.90)\end{array}$ & $\begin{array}{l}0.778^{* * *} \\
(2.40)\end{array}$ \\
\hline $\begin{array}{l}\text { Industry concentra- } \\
\text { tion }\end{array}$ & & & $\begin{array}{l}-10.060 * * * \\
(-3.95)\end{array}$ & $\begin{array}{l}-10.090 * * * \\
(-3.91)\end{array}$ & $\begin{array}{l}4.953 * * * \\
(3.91)\end{array}$ & $\begin{array}{l}4.906^{* * * *} \\
(3.95)\end{array}$ \\
\hline Year & Yes & Yes & Yes & Yes & Yes & Yes \\
\hline Wald $\mathrm{Chi}^{2}$ & $3683.25^{* * *}$ & $3727.70 * * *$ & $1070.13^{* * *}$ & $1078.08 * * *$ & $566.52 * * *$ & $589.90^{* * * *}$ \\
\hline $\mathrm{AR}(1)$ & $-14.163^{* * *}$ & $-13.987 * * *$ & $-13.231 * * *$ & $-13.212 * * *$ & $-10.338^{* * *}$ & $-10.368^{* * *}$ \\
\hline $\mathrm{AR}(2)$ & 0.001 & -0.030 & 0.020 & 0.018 & -0.596 & -0.597 \\
\hline $\begin{array}{l}\text { Number of observa- } \\
\text { tions }\end{array}$ & 22,836 & 22,836 & 22,833 & 22,833 & 22,833 & 22,833 \\
\hline
\end{tabular}

This table presents the quarterly GMM regressions. The dependent variable is operating margin in columns (1) and (2), trade receivables in columns (3) and (4) and trade payables in columns (5) and (6). The GMM regressions are estimated using the Arellano and Bond (1991) one-step GMM difference estimator for panel data with lagged dependent variables. The linear regressions are displayed in odd numbered columns and non-linear regressions in even columns. D is a dummy variable taking value one if the corresponding inventory is abnormally high and 0 otherwise. Variable definitions are provided in "Appendix 3"

*Significance at the $10 \%$ level

**Significance at the $5 \%$ level

$* * *$ Significance at the $1 \%$ level 
Table 10 Industry adjusted abnormal inventory regressions

\begin{tabular}{|c|c|c|c|c|c|c|}
\hline \multirow[t]{2}{*}{ Variables } & \multicolumn{2}{|c|}{ Operating margin } & \multicolumn{2}{|c|}{ Trade receivables } & \multicolumn{2}{|c|}{ Trade payables } \\
\hline & (1) & (2) & (3) & (4) & (5) & (6) \\
\hline Operating margin $_{, t-1}$ & $\begin{array}{l}0.672 * * * \\
(18.077)\end{array}$ & $\begin{array}{l}0.664 * * * \\
(18.075)\end{array}$ & & & & \\
\hline Trade receivables $_{, t-1}$ & & & $\begin{array}{l}0.071 * * * \\
(2.930)\end{array}$ & $\begin{array}{l}0.070 * * * \\
(2.925)\end{array}$ & & \\
\hline Trade payables $_{, t-1}$ & & & & & $\begin{array}{l}0.115^{*} \\
(1.724)\end{array}$ & $\begin{array}{l}0.114^{*} \\
(1.712)\end{array}$ \\
\hline Abnormal inventory & $\begin{array}{l}-0.101 * * \\
(-1.975)\end{array}$ & & $\begin{array}{l}0.085 \\
(1.454)\end{array}$ & & $\begin{array}{l}0.118^{* * * *} \\
(4.181)\end{array}$ & \\
\hline $\begin{array}{l}\text { Abnormal inven- } \\
\text { tory } \times \mathrm{D}\end{array}$ & & $\begin{array}{l}-1.273 * * * \\
(-6.861)\end{array}$ & & $\begin{array}{l}-1.746 * * * \\
(-8.951)\end{array}$ & & $\begin{array}{l}-0.048 \\
(-0.799)\end{array}$ \\
\hline $\begin{array}{l}\text { Abnormal inven- } \\
\text { tory } \times(1-D)\end{array}$ & & $\begin{array}{l}0.989 * * * \\
(5.663)\end{array}$ & & $\begin{array}{l}0.007 \\
(1.640)\end{array}$ & & $\begin{array}{l}0.271 * * * \\
(3.845)\end{array}$ \\
\hline Firm risk & $\begin{array}{l}0.640 * * * \\
(2.694)\end{array}$ & $\begin{array}{l}0.612 * * * \\
(2.642)\end{array}$ & & & & \\
\hline Fixed asset growth & $\begin{array}{l}-0.067 * * * \\
(-3.369)\end{array}$ & $\begin{array}{l}-0.063 * * * \\
(-3.177)\end{array}$ & & & & \\
\hline $\mathrm{R} \& \mathrm{D}$ & $\begin{array}{l}0.869 * * * \\
(10.749)\end{array}$ & $\begin{array}{l}0.868 * * * \\
(10.892)\end{array}$ & & & & \\
\hline Firm size & $\begin{array}{l}-0.554 \\
(-1.608)\end{array}$ & $\begin{array}{l}-0.558^{*} \\
(-1.667)\end{array}$ & $\begin{array}{l}0.865^{* * * *} \\
(3.961)\end{array}$ & $\begin{array}{l}0.819 * * * \\
(3.847)\end{array}$ & $\begin{array}{l}0.481^{* * *} * \\
(3.589)\end{array}$ & $\begin{array}{l}0.477 * * * \\
(3.563)\end{array}$ \\
\hline Firm age & $\begin{array}{l}-0.195 * * * \\
(-3.503)\end{array}$ & $\begin{array}{l}-0.167 * * * \\
(-3.042)\end{array}$ & $\begin{array}{l}-0.195 * * * \\
(-3.842)\end{array}$ & $\begin{array}{l}-0.161 * * * \\
(-3.185)\end{array}$ & $\begin{array}{l}-0.152 * * * \\
(-4.342)\end{array}$ & $\begin{array}{l}-0.149 * * * \\
(-4.280)\end{array}$ \\
\hline Leverage & $\begin{array}{l}-0.030^{*} \\
(-1.765)\end{array}$ & $\begin{array}{l}-0.037 * * \\
(-2.136)\end{array}$ & $\begin{array}{l}-0.017 \\
(-1.327)\end{array}$ & $\begin{array}{l}-0.027 * * \\
(-2.113)\end{array}$ & $\begin{array}{l}-0.007 \\
(-0.873)\end{array}$ & $\begin{array}{l}-0.007 \\
(-0.984)\end{array}$ \\
\hline Sales growth & $\begin{array}{l}0.014 * * * \\
(3.235)\end{array}$ & $\begin{array}{l}0.012 * * * \\
(2.723)\end{array}$ & $\begin{array}{l}-0.030 \\
(-1.611)\end{array}$ & $\begin{array}{l}-0.032 * \\
(-1.682)\end{array}$ & $\begin{array}{l}-0.030 * * * \\
(-3.350)\end{array}$ & $\begin{array}{l}-0.030 * * * \\
(-3.361)\end{array}$ \\
\hline Bank credit & & & $\begin{array}{l}0.041 * * * \\
(4.778)\end{array}$ & $\begin{array}{l}0.029 * * * \\
(3.550)\end{array}$ & $\begin{array}{l}0.006^{*} \\
(1.952)\end{array}$ & $\begin{array}{l}0.005 \\
(1.632)\end{array}$ \\
\hline $\begin{array}{l}\text { Financial distress } \\
\text { dummy }\end{array}$ & & & $\begin{array}{l}0.009 * * \\
(2.560)\end{array}$ & $\begin{array}{l}0.008 * * \\
(2.375)\end{array}$ & $\begin{array}{l}0.016^{* * * *} \\
(6.821)\end{array}$ & $\begin{array}{l}0.016^{* * * *} \\
(6.808)\end{array}$ \\
\hline $\begin{array}{l}\text { Industry concentra- } \\
\text { tion }\end{array}$ & & & $\begin{array}{l}0.032 * * * \\
(2.630)\end{array}$ & $\begin{array}{l}0.032 * * * \\
(2.660)\end{array}$ & $\begin{array}{l}0.013^{* * *} * \\
(4.045)\end{array}$ & $\begin{array}{l}0.013 * * * \\
(4.055)\end{array}$ \\
\hline Year & Yes & Yes & Yes & Yes & Yes & Yes \\
\hline Wald $\mathrm{Chi}^{2}$ & $504.16^{* * * *}$ & $519.34 * * *$ & $93.67 * * *$ & $178.02^{* * * *}$ & $143.38 * * *$ & $144.58 * * *$ \\
\hline AR (1) & $-14.163 * * *$ & $-13.987 * * *$ & $-13.231 * * *$ & $-13.212^{* * *}$ & $-10.338 * * *$ & $-10.368^{* * *}$ \\
\hline $\operatorname{AR}(2)$ & 0.001 & -0.030 & 0.020 & 0.018 & -0.596 & -0.597 \\
\hline $\begin{array}{l}\text { Number of observa- } \\
\text { tions }\end{array}$ & 4476 & 4476 & 4476 & 4476 & 4476 & 4476 \\
\hline
\end{tabular}

This table presents the industry adjusted abnormal inventory GMM regressions. The dependent variable is operating margin in columns (1) and (2), trade receivables in columns (3) and (4) and trade payables in columns (5) and (6). The GMM regressions are estimated using the Arellano and Bond (1991) one-step GMM difference estimator for panel data with lagged dependent variables. The linear regressions are displayed in odd numbered columns and non-linear regressions in even columns. D is a dummy variable taking value one if the corresponding inventory is abnormally high and 0 otherwise. Variable definitions are provided in "Appendix 3"

*Significance at the $10 \%$ level

$* *$ Significance at the $5 \%$ level

***Significance at the $1 \%$ level 
year is computed by subtracting the industry mean inventory ratio from the firm actual inventory ratio of the corresponding year.

Table 10 reports the results of the operating performance, trade receivables, and trade payables regressions. The same econometric approach and the same set of control variables as in Table 5 are used. The dependent variable is operating margin in columns (1) and (2), trade receivables in columns (3) and (4), and trade payables in columns (5) and (6). The explanatory variable of interest in all columns is abnormal inventory. The results in all columns are qualitatively similar to the results contained in Table 5, indicating our main findings are robust to the method used to measure abnormal inventory.

\subsubsection{Alternative measures of dependent variables}

The operating margin regressions in Table 5 show that firms which are able to optimise their inventory enjoy higher operating performance. Since operating efficiency positively reflects in firm market performance (Beccalli et al. 2006), we expect firms to improve their stock performance as they become efficient in managing their inventory. Following previous studies (Hill et al. 2012; Aktas et al. 2015; Goto et al. 2015), we use excess return as a measure of stock performance. The excess return is measured as the difference between firm i buy-and-hold investment return and the buy-and-hold investment return in the benchmark group. The benchmark is selected to account for likely elements that may affect excess return. After that, the unexplained is judged to be abnormal and attributed to the outcome of this study. The abnormal excess return is calculated as:

$$
\text { ExRet }_{i}=\prod_{t=1}^{T}\left(1+\text { Rate }_{i t}\right)-\prod_{t=1}^{T}\left(1+\text { Rate }_{b t}\right),
$$

where ExRet, is the abnormal return for buy-and-hold stock í, Rate ${ }_{i t}$ is the monthly stock rate of return, Rate ${ }_{b t}$ is the benchmark stock return rate, and $\mathrm{T}$ is the number of months of investment, taken from Fama and French (1993). ${ }^{8}$

We also re-define trade receivables by scaling it with total assets and trade payables with total assets and cost of sales. Similar studies have also defined trade receivables and trade payables using these measures (Ferrando and Mulier 2013; Lin and Chou 2015).

Table 11 contains the results of using alternative measures of firm performance, trade receivables, and trade payables. The econometric and control variables used are the same as in Table 5. The dependent variable is operating margin in columns (1) and (2), trade receivables in columns (3) and (4), and trade payables in columns (5) to (8). In all columns the variable of interest is abnormal inventory. The results are to a large extent in congruence with the ones displayed in Table 5, which suggests that our main results are not vulnerable to alternative measures.

\subsubsection{Abnormal finished goods and raw materials}

So far in this study, we have used the total combined inventories amount, but inventories are made up of raw materials, work-in-progress and finished goods (Capkun et al. 2009). Specifically, raw materials increase through purchases whereas finished goods decrease as a result of sales. Therefore, it is ideally expected for raw materials to be affected by trade payables

\footnotetext{
${ }^{8}$ The book-to-market and size portfolio breakpoints and return by Ken French can be found at: http://mba. tuck.dartmouth.edu/pages/faculty/ken.french/data_library.html.
} 


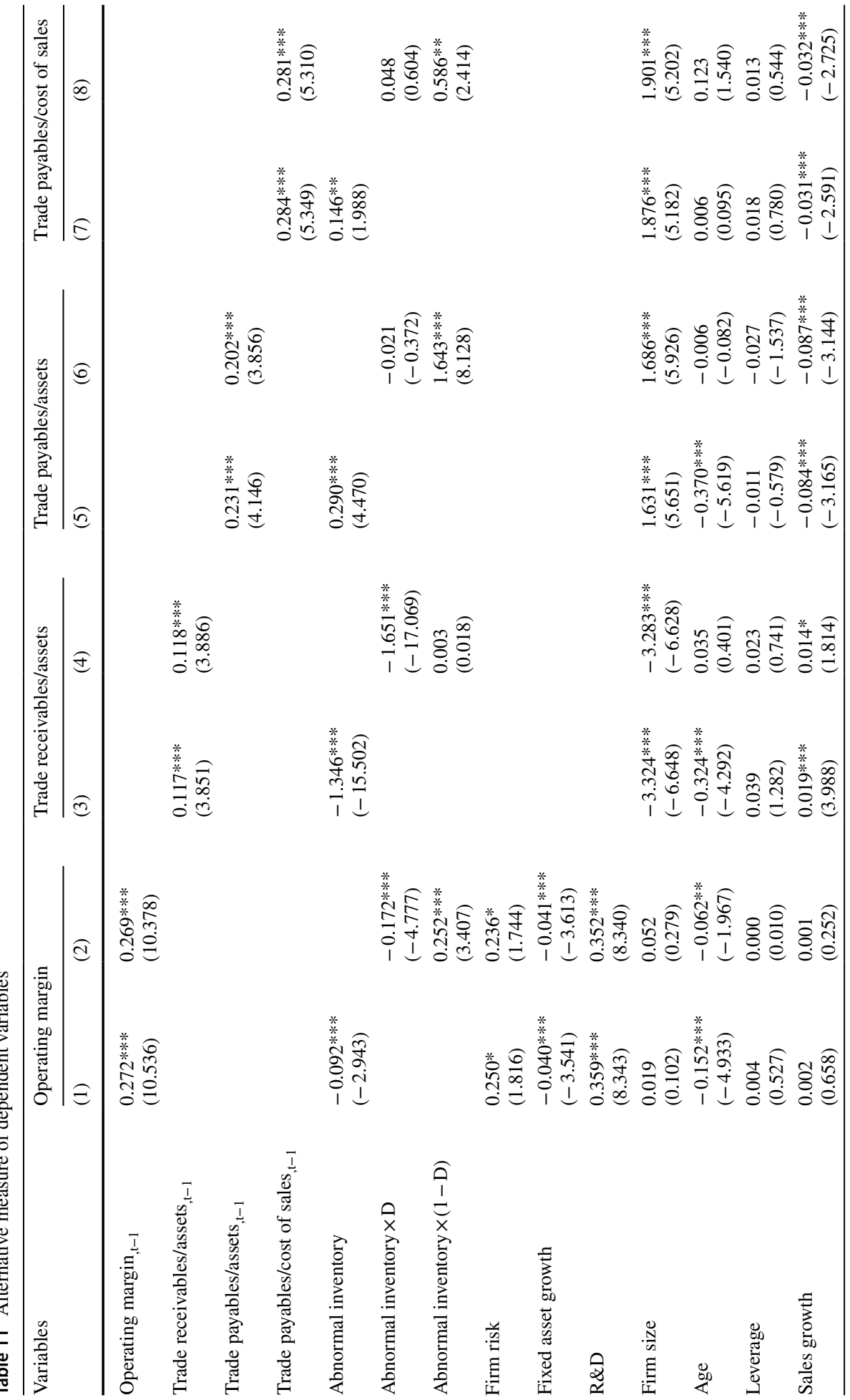




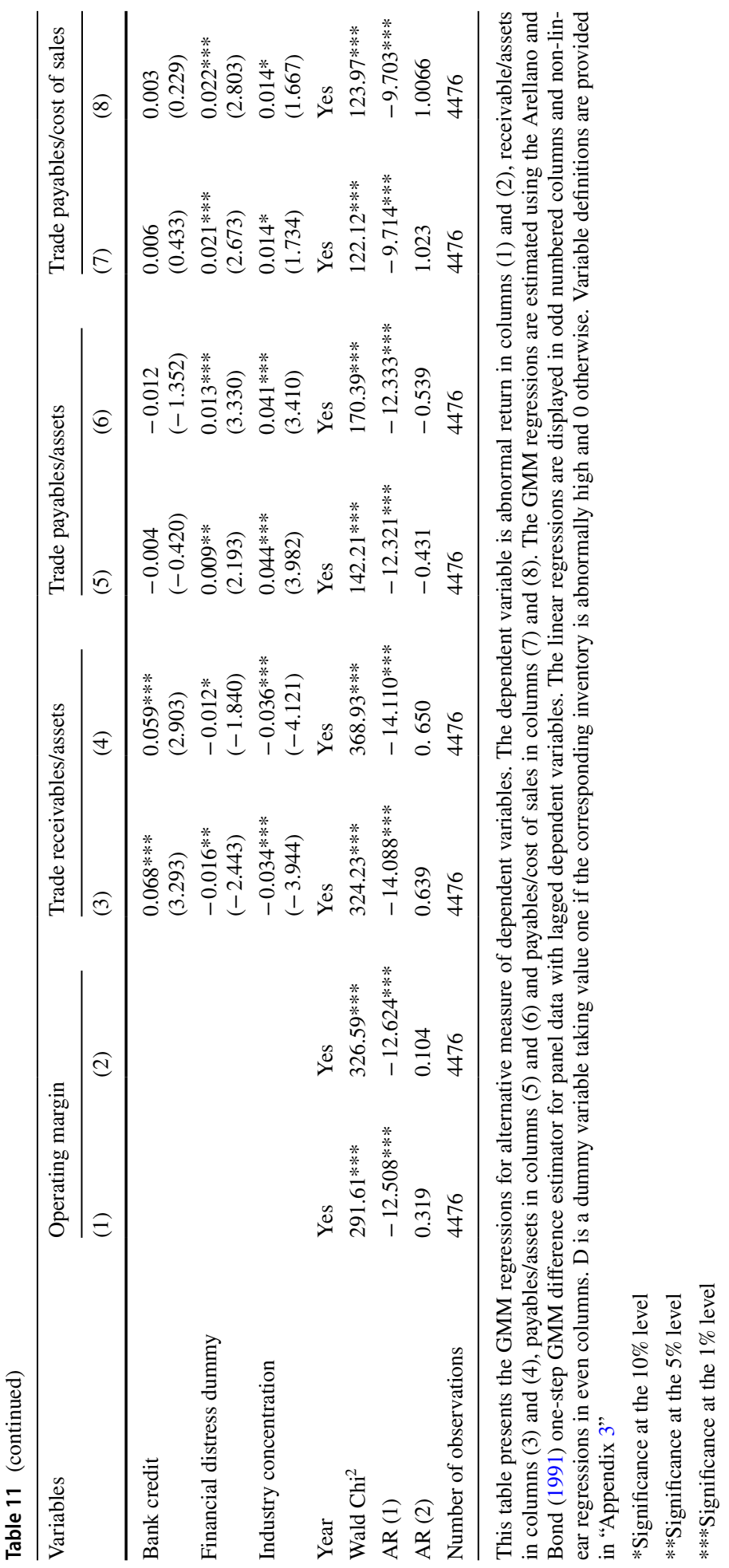


Table 12 Finished goods and raw materials

\begin{tabular}{|c|c|c|c|c|}
\hline \multirow[t]{2}{*}{ Variables } & \multicolumn{2}{|c|}{ Trade receivables } & \multicolumn{2}{|c|}{ Trade payables } \\
\hline & (1) & (2) & (3) & (4) \\
\hline Trade receivables $_{, \mathrm{t}-1}$ & $\begin{array}{l}0.075 * * * \\
(3.112)\end{array}$ & $\begin{array}{l}0.063 * * * \\
(2.631)\end{array}$ & & \\
\hline Trade payables $_{, t-1}$ & & & $\begin{array}{l}0.116^{*} \\
(1.719)\end{array}$ & $\begin{array}{l}0.110^{*} \\
(1.706)\end{array}$ \\
\hline Abnormal finished goods & $\begin{array}{l}-0.678^{* * *} * \\
(-8.023)\end{array}$ & & & \\
\hline Abnormal finished goods $\times \mathrm{D}$ & & $\begin{array}{l}-1.030 * * * \\
(-9.954)\end{array}$ & & \\
\hline Abnormal finished goods $\times(1-D)$ & & $\begin{array}{l}0.085 \\
(0.638)\end{array}$ & & \\
\hline Abnormal raw materials & & & $\begin{array}{l}0.010 \\
(0.209)\end{array}$ & \\
\hline Abnormal raw materials $\times D$ & & & & $\begin{array}{l}-0.022 \\
(-0.580)\end{array}$ \\
\hline Abnormal raw materials $\times(1-D)$ & & & & $\begin{array}{l}0.442 * * * \\
(5.020)\end{array}$ \\
\hline Firm size & $\begin{array}{l}0.912 * * * \\
(4.149)\end{array}$ & $\begin{array}{l}0.957 * * * \\
(4.286)\end{array}$ & $\begin{array}{l}0.505^{* * *} * \\
(3.744)\end{array}$ & $\begin{array}{l}0.520 * * * \\
(3.898)\end{array}$ \\
\hline Age & $\begin{array}{l}-0.352 * * * \\
(-7.241)\end{array}$ & $\begin{array}{l}-0.141 * * * \\
(-2.762)\end{array}$ & $\begin{array}{l}-0.157 * * * \\
(-4.453)\end{array}$ & $\begin{array}{l}-0.045 \\
(-1.362)\end{array}$ \\
\hline Leverage & $\begin{array}{l}-0.011 \\
(-0.826)\end{array}$ & $\begin{array}{l}-0.019 \\
(-1.344)\end{array}$ & $\begin{array}{l}-0.008 \\
(-1.026)\end{array}$ & $\begin{array}{l}-0.012 \\
(-1.636)\end{array}$ \\
\hline Sales growth & $\begin{array}{l}-0.025 \\
(-1.415)\end{array}$ & $\begin{array}{l}-0.028^{*} \\
(-1.651)\end{array}$ & $\begin{array}{l}-0.029 * * * \\
(-3.302)\end{array}$ & $\begin{array}{l}-0.031 * * * \\
(-3.299)\end{array}$ \\
\hline Bank credit & $\begin{array}{l}0.050 * * * \\
(6.175)\end{array}$ & $\begin{array}{l}0.047 * * * \\
(5.871)\end{array}$ & $\begin{array}{l}0.004 \\
(1.451)\end{array}$ & $\begin{array}{l}0.002 \\
(0.565)\end{array}$ \\
\hline Financial distress dummy & $\begin{array}{l}0.006 \\
(1.629)\end{array}$ & $\begin{array}{l}0.008 * * \\
(2.363)\end{array}$ & $\begin{array}{l}0.016^{* * * *} \\
(6.694)\end{array}$ & $\begin{array}{l}0.018 * * * \\
(7.405)\end{array}$ \\
\hline Industry concentration & $\begin{array}{l}0.032 * * \\
(2.156)\end{array}$ & $\begin{array}{l}0.030 * \\
(1.903)\end{array}$ & $\begin{array}{l}0.013 * * * \\
(3.909)\end{array}$ & $\begin{array}{l}0.012 * * * \\
(3.711)\end{array}$ \\
\hline Year & Yes & Yes & Yes & Yes \\
\hline Wald $\mathrm{Chi}^{2}$ & $167.39 * * *$ & $190.59 * * *$ & $142.04 * * *$ & $151.69 * * *$ \\
\hline $\operatorname{AR}(1)$ & $-9.082 * * *$ & $-9.025 * * *$ & $-6.043 * * *$ & $-6.246^{* * *}$ \\
\hline $\operatorname{AR}(2)$ & 0.107 & 0.269 & -0.902 & -1.073 \\
\hline Number of observations & 4476 & 4476 & 4476 & 4476 \\
\hline
\end{tabular}

This table presents the GMM regressions. The dependent variable is trade receivables in columns (1) and (2) and trade payables in columns (3) and (4). The GMM regressions are estimated using the Arellano and Bond (1991) one-step GMM difference estimator for panel data with lagged dependent variables. The linear regressions are displayed in odd numbered columns and non-linear regressions in even columns. D is a dummy variable taking value one if the corresponding inventory is abnormally high and 0 otherwise. Variable definitions are provided in "Appendix 3"

*Significance at the $10 \%$ level

$* *$ Significance at the $5 \%$ level

$* * *$ Significance at the $1 \%$ level 
and finished goods expected to be affected by trade receivables (Lin and Chou 2015). This section examines how raw materials and finished goods behaviour affect trade payables and trade receivables, respectively. Previous studies have shown that the three types of inventories behave differently. For example, Rajagopalan and Malhotra (2001) show in their study that raw materials and work-in-progress decreased between 1961 and 1994 in the USA whereas finished goods increased during the same period.

To investigate how trade payables and trade receivables are affected by abnormal raw materials and finished goods, respectively, we follow the same procedure used in calculating abnormal inventories above. First, we scale raw materials and finished goods by sales revenue, predict raw materials-sales ratio and finished goods-sales ratio using the same variables employed above (financial distress, sales growth, firm size, sales volatility, capital expenditure, firm age, and operating cash flow) and then calculate abnormal raw materials and abnormal finished goods. Second, we estimate both the abnormally high and low raw materials and finished goods. Therefore, $\boldsymbol{D}$ is a dummy variable which denotes value 1 if the corresponding abnormal raw materials and finished goods is positive, and 0 for negative.

The results are contained in Table 12. Columns (1) and (2) present the trade receivables regressions, and columns (3) and (4) present the trade payables regressions. The explanatory variable of interest in columns (1) and (2) is abnormal finished goods and abnormal raw materials in columns (3) and (4). Column (1) shows a linear negative relationship between abnormal finished goods and trade receivables $(\beta=-0.678$, t-statistic $=-8.023)$. Column (2) reports the results of the asymmetric model, which replaces the abnormal finished goods with two interactive terms: (abnormal finished goods $* \boldsymbol{D})$ and [abnormal finished goods $*(1-\boldsymbol{D}$ )]. The dummy variable $\boldsymbol{D}$ identifies firms with abnormally high finished goods. Therefore, $(1-\boldsymbol{D})$ also identifies firms with abnormally low finished goods. The results show that only a decrease in abnormally high finished goods is associated with trade receivables. Specifically, the coefficient estimate of the interaction variable (abnormal finished goods $* \boldsymbol{D}$ ) is negative and statistically significant $(\beta=-1.030, t$-statistic $=-9.954)$ whereas the coefficient estimate of the interaction variable [abnormal finished goods $*(1-\boldsymbol{D})$ ] is not statistically significant $(\beta=0.085$, t-statistic $=0.638)$. This confirms previous studies which state that firms reduce abnormal finished goods through the increase of trade receivables.

Column (3) shows an insignificant relationship between abnormal raw materials and trade payables $(\beta=0.010$, t-statistic $=0.209)$. Column $(4)$ reports the results of the asymmetric model, which replaces the abnormal raw materials with two interactive terms: (abnormal raw materials $* \boldsymbol{D})$ and [abnormal raw materials* $(1-\boldsymbol{D})$ ]. The dummy variable $\boldsymbol{D}$ identifies firms with abnormally high raw materials. Therefore, $(1-\boldsymbol{D})$ also identifies firms with abnormally low materials. The results show that only an increase in abnormally high raw materials is associated with trade payables. Specifically, the coefficient estimate of the interaction variable [abnormal raw materials $*(1-\boldsymbol{D})]$ is positive and statistically significant $(\beta=0.442$, t-statistic $=5.020)$ whereas the coefficient estimate of the interaction variable (abnormal raw materials* $\boldsymbol{D}$ ) is not statistically significant $(\beta=-0.022$, t-statistic $=-0.580)$. This is consistent with previous studies which show that firms increase raw materials through the increase of trade payables.

\section{Conclusion}

Prior studies have mainly focused on only the normal inventory relationship with firm performance to the neglect of the effects of abnormal inventory. This is surprising, given that the normal inventory level of firms varies considerably in relation to firm-specific 
characteristics. In this study, we try to fill the gap in the literature by examining the relationship between abnormal inventory and firm performance. First, we examine the relationship between abnormal inventory and firm performance using both linear and asymmetry techniques. Second, we explore how trade receivables and trade payables impact upon the abnormal inventory and firm performance relationship. Third, we examine whether firm risk is the alternative channel that accounts for the relationship between abnormal inventory and firm performance. To do that, we focus on a sample of UK manufacturing firms over a 10-year period between 2006 and 2015.

Overall, we find that a decrease (increase) in abnormally high (low) inventory is positively associated with firm performance. In particular, firms that are able to converge to the optimal level across time, by either decreasing abnormally high inventory or increasing abnormally low inventory, can improve their operating and stock performance. More importantly, the findings provide new evidence that firms decrease abnormally high inventory and increase abnormally low inventory through trade receivables and trade payables, respectively. This improves our understanding of the possible reasons for the increase in firm performance. Also, the results rule out risk as a possible driver for the positive association between a decrease (increase) in abnormally high (low) inventory and firm performance.

Our findings have major corporate policy implications. In order to maximise their returns on inventory investment, manufacturing firms should place a greater emphasis on efficient management of their inventories that constitute a substantial proportion of their sales. Specifically, a firm that efficiently manages its inventory can potentially create additional funds, which can be invested in profit-maximising projects, and therefore maximise its shareholder value. To this end, a firm should avoid holding abnormally high or low levels of inventories in order to keep its inventory at the optimum level, which varies from one firm to another (i.e. firm-specific).

Notwithstanding insights gained from this study, there were a number of limitations upon which future studies might be concentrated. First, due to the nature of our sample, we are unable to identify firms that exclusively operate the JIT system of inventory management. However, all the firms in our sample keep a minimum of inventory, suggesting the need for inventory management and control. Second, although different inventory valuation methods (such as first-in-first-out (FIFO) or average-cost methods) will affect operating margins and inventory balance, due to the nature of our sample, we are unable from the dataset to distinguish firms that use FIFO and average-cost method of inventory valuation.

Open Access This article is licensed under a Creative Commons Attribution 4.0 International License, which permits use, sharing, adaptation, distribution and reproduction in any medium or format, as long as you give appropriate credit to the original author(s) and the source, provide a link to the Creative Commons licence, and indicate if changes were made. The images or other third party material in this article are included in the article's Creative Commons licence, unless indicated otherwise in a credit line to the material. If material is not included in the article's Creative Commons licence and your intended use is not permitted by statutory regulation or exceeds the permitted use, you will need to obtain permission directly from the copyright holder. To view a copy of this licence, visit http://creativecommons.org/licenses/by/4.0/.

\section{Appendix 1}

See Table 13. 
Table 13 The UK SIC 2007 classification of manufacturing firms

\section{Appendix 2}

See Table 14.

Table 14 Fit of the first stage OLS regression

\section{Appendix 3}

\section{See Table 15.}

Food, beverage and tobacco products

Textiles and textile products

Wood and wood products

Pulp, paper and paper products

Publishing and printing

Coke, petroleum products and nuclear fuel

Chemicals, chemical products and man-made fibres

Rubber and plastic products

Other non-metallic mineral products

Basic metals and fabricated metal products

Other machinery and equipment

Electrical and optical equipment

Transport equipment

Other manufacturing

\begin{tabular}{lllllll}
\hline & Mean & Q1 & Median & SD & Q3 & N \\
\hline Fisher-statistic & 3.4 & 2.38 & 3.22 & 1.4 & 4.1 & 140 \\
Adjusted R-square (\%) & 29.07 & 11.4 & 23.86 & 20 & 49 & 140 \\
Number of observations & 65 & 19 & 45 & 62 & 95 & 140 \\
\hline
\end{tabular}


Table 15 Variable definitions

Variable Description

Inventory-to-sales ratio

Predicted inventory-to-sales ratio

Financial distress dummy

Annual sales growth

Firm size

Sales volatility

Capital expenditure ratio

Firm age

Operating cash flow

Abnormal inventory

Industry adjusted abnormal inventory

Operating margin

Trade receivables

Industry adjusted trade receivables

Trade payables

Industry adjusted trade payables

Excess return

Firm risk

Fixed assets growth

Research and development (R\&D)

Leverage

Bank credit

Industry concentration

\section{Inventory divided by sales revenue}

For each industry, the inventory-to-sales ratio is regressed on the following lagged determinants: financial distress dummy, sales growth, firm size, sales volatility, capital expenditure, firm age and operating cash flow. The predicted inventory-to-sales ratio is the residual of this regression

Following Hill et al. (2010) and Aktas et al. (2015), a firm must satisfy two criteria to be classified as financially distressed: (1) the firm faces difficulty to cover its interest expenses and (2) the firm is overleveraged. The firm is considered having difficulties in covering interest expenses if its interest coverage ratio (i.e., operating income before depreciation divided by interest expense) is below one for two consecutive years or less than 0.80 in any given year. Concerning the second criteria, the firm is considered to be overleveraged if it belongs to the top two deciles of its industry's leverage in a given year

One-year growth rate of sales at time $\mathrm{t}-1$ : (SALEt - SALEt-1)/ SALEt - 1

Total assets of firms

Sales volatility for a given year is the standard deviation of a firm's annual sales over the previous 2-year period

The ratio of capital expenditure to total assets

Number of years between incorporation and the calendar year end of each firm

Operating income before extraordinary items + depreciation, scaled by lagged fixed assets

The difference between the actual inventory-to-sales ratio and predicted inventory-to-sales ratio for each firm per year

Abnormal inventory ratio minus the industry mean of the abnormal inventory ratio

Earnings before interest and tax divided by sales revenue

Trade receivables divided by total assets

Trade receivables minus industry average trade receivables

Trade payables divided by total assets

Trade payables minus industry average trade payables

Buy-and-hold excess stock return over the calendar year defined as:ExcessRet ${ }_{i}=\prod_{t=1}^{T}\left(1+R_{i t}\right)^{-} \prod_{t=1}^{T}\left(1+R_{b t}\right)$, where $\mathrm{R}_{\mathrm{it}}$ and $\mathrm{R}_{\mathrm{bt}}$ are the return for firm I and the return of the benchmark portfolio for month $\mathrm{m}$. Benchmark portfolios are the twenty-five Fama-French value-weighted portfolios based on size and bookto-market

Following Aktas et al. (2015), firm total risk is defined as the standard deviation of daily stock return. In the regression analyses, the annualized standard deviation of daily stock return is used

One-year growth rate of fixed assets

Research and development expenditure to total assets

Long-term debt, scaled by total assets

Short-term debt, scaled by total

Industries with Herfindahl index values exceeding the sample median annual Herfindahl index 
Table 15 (continued)

\begin{tabular}{ll}
\hline Variable & Description \\
\hline Book-to-market & Book value of equity divided by market value of equity \\
\hline
\end{tabular}

\section{References}

Abdulla Y, Dang VA, Khurshed A (2017) Stock market listing and the use of trade credit: evidence from public and private firms. J Corp Finance 46:391-410

Afrifa GA (2016) Net working capital, cash flow and performance of UK SMEs. Rev Account Finance $15: 21-44$

Afrifa GA, Gyapong E (2017) Net trade credit: what are the determinants? Int J Manag Finance 13:246-266

Aktas N, Croci E, Petmezas D (2015) Is working capital management value-enhancing? Evidence from firm performance and investments. J Corp Finance 30:98-113

Arellano M, Bond S (1991) Some tests of specification for panel data: Monte Carlo evidence and an application to employment equations. Rev Econ Stud 58:277-297

Ballou RH (2000) Evaluating inventory management performance using a turnover curve. Int J Phys Distrib Logist Manag 30:72-85

Banker RD, Byzalov D, Fang S, Jin B (2019) Operating asymmetries and non-linear spline correction in discretionary accrual models. Rev Quant Finance Account 54:1-48

Baños-Caballero S, García-Teruel PJ, Martínez-Solano P (2014) Working capital management, corporate performance, and financial constraints. J Bus Res 67:332-338

Bao B-H, Bao D-H (2004) Change in inventory and firm valuation. Rev Quant Finance Account 22:53-71

Beccalli E, Casu B, Girardone C (2006) Efficiency and stock performance in European banking. J Bus Finance Account 33:245-262

Bernard V, Noel J (1991) Do inventory disclosures predict sales and earnings? J Account Audit Finance 6:145-181

Bhattacharya H (2008) Theories of trade credit: limitations and applications. http://ssrn.com/abstract=12864 43

Blinder AS, Maccini LJ (1991) The resurgence of inventory research: what have we learned? J Econ Surv 5:291-328

Bougheas S, Mateut S, Mizen P (2009) Corporate trade credit and inventories: new evidence of a trade-off from accounts payable and receivable. J Bank Finance 33:300-307

Cachon G, Fisher M (1997) Campbell soup's continuous replenishment program: evaluation and enhanced inventory decision rules. Prod Oper Manag 6:266-276

Caglayan M, Maioli S, Mateut S (2012) Inventories, sales uncertainty, and financial strength. J Bank Finance 36:2512-2521

Capkun V, Hameri A-P, Weiss LA (2009) On the relationship between inventory and financial performance in manufacturing companies. Int J Oper Prod Manag 29:789-806

Chen H, Frank MZ, Wu OQ (2005) What actually happened to the inventories of American companies between 1981 and 2000? Manag Sci 51:1015-1031

Chen H, Frank MZ, Wu OQ (2007) US retail and wholesale inventory performance from 1981 to 2004. Manuf Serv Oper Manag 9:430-456

Choi WG, Kim Y (2005) Trade credit and the effect of macro-financial shocks: evidence from US panel data. J Financ Quant Anal 40:897-925

Chowdhury A, Amin MM (2007) Working capital management practiced in pharmaceutical companies listed in Dhaka stock exchange. BRAC Univ J IV(2):75-86

Cohen DA, Zarowin P (2010) Accrual-based and real earnings management activities around seasoned equity offerings. J Account Econ 50:2-19

Corsten D, Gruen TW (2004) Stock-outs cause walkouts. Harv Bus Rev 82:26-28

Deloof M (2003) Does working capital management affect profitability of Belgian firms? J Bus Finance Account 30:573-588

Deloof M, Jegers M (1999) Trade credit, corporate groups, and the financing of Belgian firms. J Bus Finance Account 26:945-966

Deloof M, La Rocca M (2015) Local financial development and the trade credit policy of Italian SMEs. Small Bus Econ 44:905-924

Demeter K (2003) Manufacturing strategy and competitiveness. Int J Prod Econ 81:205-213 
Demirgüç-Kunt A, Maksimovic V (1999) Institutions, financial markets, and firms' choice of debt maturity. The World Bank, Washington, DC

Drury CM (2013) Management and cost accounting. Springer, Berlin

Ek R, Guerin S (2011) Is there a right level of working capital? J Corp Treas Manag 4:137-149

Enos BK, Gyapong E (2017) Board diversity, corporate governance quality and excess CEO pay: evidence from South Africa. Int J Corp Gov 8:175-204

Fama EF, French KR (1993) Common risk factors in the returns on stocks and bonds. J Financ Econ $33: 3-56$

Ferrando A, Mulier K (2013) Do firms use the trade credit channel to manage growth? J Bank Finance 37:3035-3046

Ferris JS (1981) A transactions theory of trade credit use. Q J Econ 96:243-270

Field A (2013) Discovering statistics using IBM SPSS statistics. Sage, London

Fullerton RR, McWatters CS, Fawson C (2003) An examination of the relationships between JIT and financial performance. J Oper Manag 21:383-404

García-Teruel PJ, Martínez-Solano P (2007) Effects of working capital management on SME profitability. Int J Manag Finance 3:164-177

García-Teruel PJ, Martínez-Solano P (2010) A dynamic perspective on the determinants of accounts payable. Rev Quant Finance Account 34:439-457

Gaur V, Fisher ML, Raman A (2005) An econometric analysis of inventory turnover performance in retail services. Manag Sci 51:181-194

Gonzalez VM, González F (2008) Influence of bank concentration and institutions on capital structure: new international evidence. J Corp Finance 14:363-375

Goto S, Xiao G, Xu Y (2015) As told by the supplier: trade credit and the cross section of stock returns. J Bank Finance 60:296-309

Gu Z, Lee C-WJ, Rosett JG (2005) What determines the variability of accounting accruals? Rev Quant Finance Account 24:313-334

Guariglia A (1999) The effects of financial constraints on inventory investment: evidence from a panel of UK firms. Economica 66:43-62

Guariglia A, Mateut S (2016) External finance and trade credit extension in China: does political affiliation make a difference? Eur J Finance 22:319-344

Gujarati DN, Porter DC (2009) Basic econometrics, 5th edn. McGraw-HiII, New York

Gysegom W, Sabah R, Schlichter M et al (2019) Brexit: the bigger picture-rethinking supply chains in a time of uncertainty. McKinsey Co., New York

Halabi H, Alshehabi A, Zakaria I (2019) Informal institutions and managers' earnings management choices: evidence from IFRS-adopting countries. J Contemp Account Econ 15:100162

Harrison A (1992) Just-in-Time: manufacturing in perspective. Prentice Hall, London

Hendricks KB, Singhal VR (2005) An empirical analysis of the effect of supply chain disruptions on long-run stock price performance and equity risk of the firm. Prod Oper Manag 14:35-52

Hendricks KB, Singhal VR (2014) The effect of demand-supply mismatches on firm risk. Prod Oper Manag 23:2137-2151

Hill NC, Sartoris WL (1992) Short-term financial management: text and cases. Macmillan Publishing Company, New York

Hill MD, Kelly GW, Highfield MJ (2010) Net operating working capital behavior: a first look. Financ Manag 39:783-805

Hill MD, Kelly GW, Lockhart GB (2012) Shareholder returns from supplying trade credit. Financ Manag 41:255-280

Hsieh P-J, Kleiner BH (1992) New developments in inventory and materials management. Logist Inf Manag 5:32-35

Huson M, Nanda D (1995) The impact of Just-in-Time manufacturing on firm performance in the US. J Oper Manag 12:297-310

Johnson A (1986) MRP? MRPII? OPT? CIM? FMS? JIT? Is any system letter-perfect? Manag Rev 75:22-27

Kieschnick R, Laplante M, Moussawi R (2013) Working capital management and shareholders' wealth. Rev Finance 17:1827-1852

Kinney MR, Wempe WF (2002) Further evidence on the extent and origins of JIT's profitability effects. Account Rev 77:203-225

Kothari SP, Leone AJ, Wasley CE (2005) Performance matched discretionary accrual measures. J Account Econ. https://doi.org/10.1016/j.jacceco.2004.11.002

Lau CM, Schaede U (2019) Of substitutes and complements: trade credit versus bank loans in Japan, 19802012. Rev Quant Finance Account. https://doi.org/10.1007/s11156-019-00844-1

Lev B, Thiagarajan SR (1993) Fundamental information analysis. J Account Res 31:190-215 
Li D (2014) Dissecting and connecting the growth and accounting distortion components of accruals. Rev Quant Finance Account 42:1-28

Lin T-T, Chou J-H (2015) Trade credit and bank loan: evidence from Chinese firms. Int Rev Econ Finance 36:17-29

Long MS, Malitz IB, Ravid SA (1993) Trade credit, quality guarantees, and product marketability. Financ Manag 22:117-127

Madhou A, Moosa I, Ramiah V (2015) Working capital as a determinant of corporate profitability. Rev Pac Basin Financ Mark Policies 18:1550024. https://doi.org/10.1142/S0219091515500241

Martínez-Sola C, García-Teruel PJ, Martínez-Solano P (2014) Trade credit and SME profitability. Small Bus Econ 42:561-577

Mateut S, Mizen P, Ziane Y (2015) Inventory composition and trade credit. Int Rev Financ Anal 42:434-446

Mendelson H, Parlaktürk AK (2008) Competitive customization. Manuf Serv Oper Manag 10:377-390

Mian SL, Smith CW Jr (1992) Accounts receivable management policy: theory and evidence. J Finance 47:169-200

Monden Y (1983) Toyota production system. Industrial Engineering and Management Press, Norcross

Morgan DP (1991) Will Just-In-Time inventory techniques dampen recessions? Fed Reserv Bank Kansas City Econ Rev 2:21-33

Nilsen JH (2002) Trade credit and the bank lending channel. J Money Credit Bank 34:226-253

Obermaier R, Donhauser A (2012) Zero inventory and firm performance: a management paradigm revisited. Int J Prod Res 50:4543-4555

Office for National Statistics (2019a) GDP monthly estimate, UK: February 2019. Office for National Statistics, London

Office for National Statistics (2019b) GDP monthly estimate, UK: October 2019. Office for National Statistics, London

Peel MJ, Wilson N, Howorth C (2000) Late payment and credit management in the small firm sector: some empirical evidence. Int Small Bus J 18:17-37

Petersen MA, Rajan RG (1997) Trade credit: theories and evidence. Rev Financ Stud 10:661-691

Pfeifer S (2019) Manufacturers fear flipside of no-deal Brexit boom. The Financial Times

Pong CKM, Mitchell F (2012) Inventory investment and control: how have UK companies been doing? $\mathrm{Br}$ Account Rev 44:173-188

Pooler M (2019) How Brexit uncertainty is weighing on UK manufacturing. The Financial Times

Rajagopalan S, Malhotra A (2001) Have US manufacturing inventories really decreased? An empirical study. Manuf Serv Oper Manag 3:14-24

Raman A (1997) Module overview: coordinating and managing supply chains—matching supply and demand. Harvard Business School Press, Boston

Shin H-H, Soenen L (1998) Efficiency of working capital management and corporate profitability. Financ Pract Educ 8:37-45

Singhal VR (2005) Excess inventory and long-term stock price performance. College of Management, Georgia Institute of Technology, Atlanta

Valderrama MT (2003) The role of trade credit and bank lending relationships in the transmission mechanism in Austria. In: Angeloni I, Kashyap A, Mojon B (eds) Monetary policy transmission in the Euro Area. Cambridge University Press, Cambridge

Van Horenbeek A, Buré J, Cattrysse D et al (2013) Joint maintenance and inventory optimization systems: a review. Int J Prod Econ 143:499-508

Wang Y-J (2002) Liquidity management, operating performance, and corporate value: evidence from Japan and Taiwan. J Multinatl Financ Manag 12:159-169

Wen Y (2005) Understanding the inventory cycle. J Monet Econ 52:1533-1555

Xu H, Dao M, Wu J (2019) The effect of local political corruption on earnings quality. Rev Quant Finance Account 53:551-574. https://doi.org/10.1007/s11156-018-0758-X

$\mathrm{Xu} \mathrm{H}$, Wu J, Dao M (2020) Corporate social responsibility and trade credit. Rev Quant Finance Account 54:1389-1416. https://doi.org/10.1007/s11156-019-00829-0

Younies H, Barhem B, Hsu CE (2007) A review of the adoption of Just-In-Time method and its effect on efficiency. Public Adm Manag 12:25

Publisher's Note Springer Nature remains neutral with regard to jurisdictional claims in published maps and institutional affiliations. 